Departement für Kleintiere, Klinik für Zoo-, Heim- und Wildtiere der Vetsuisse-Fakultät Universität Zürich

Direktor: Prof. Dr. Jean-Michel Hatt

Arbeit unter wissenschaftlicher Betreuung von

Prof. Dr. Marcus Clauss

Digestive physiology, metabolism and methane production of captive Linné's two-toed sloths (Choloepus didactylus)

Inaugural-Dissertation

zur Erlangung der Doktorwürde der

Vetsuisse-Fakultät Universität Zürich

vorgelegt von

\title{
Catharina Vendl
}

Tierärztin

von Berlin, Deutschland

genehmigt auf Antrag von

Prof. Dr. Marcus Clauss

Zürich 2015 
Inhaltsverzeichnis

Zusammenfassung

Artikel

Digestive physiology, metabolism and methane

3-38

production of captive Linné's two-toed

sloths (Choloepus didactylus)

Vendl C, Frei S, Dittmann, M, Furrer S, Osmann C, Ortmann S, Munn A, Kreuzer M, Clauss, M, 2015

Journal of Animal Physiology and Animal Nutrition (online) doi 10.1111/jpn.12356

Lebenslauf 


\title{
Vetsuisse-Fakultät Universität Zürich (2015)
}

\author{
Catharina Vendl \\ Departement für Kleintiere
}

Klinik für Zoo-, Heim- und Wildtiere

ehuber@vetclinics.uzh.ch

\begin{abstract}
Digestive physiology, metabolism and methane production of captive Linné's two-toed sloths (Choloepus didactylus)
\end{abstract}

\begin{abstract}
Summary
Sloths are renowned for their low metabolic rate (MR), low food intake and low defecation frequency (DF). We investigated factors of digestive physiology and metabolism in four captive individuals $(10.0 \pm 3.7 \mathrm{~kg})$ of the hitherto mostly unstudied Linné's two-toed sloth (Choloepus didactylus), with 2-week feeding and 24-h respiration experiments on a standard zoo diet. Dry matter intake (DMI), DF and particle mean retention time (MRT) in the gastrointestinal tract (GIT) were $12 \pm 3 \mathrm{~g} \mathrm{~kg}^{-0.75} \mathrm{~d}^{-1}$, every 5 days and $>140 \mathrm{~h}$ in three individuals but $53 \mathrm{~g} \mathrm{~kg}^{-0.75} \mathrm{~d}^{-1}$, daily and $82 \mathrm{~h}$ in one individual compensating for a period of previous weight loss. Solute marker was faster excreted than particle marker, indicating 'digesta washing'. The overall MR measured by oxygen consumption matched the metabolisable energy intake in 3 individuals $\left(173 \pm 22\right.$ vs. $\left.168 \pm 44 \mathrm{~kJ} \mathrm{~d}^{-1} \mathrm{~kg}^{-0.75}\right)$ but not in the fourth (225 vs. $698 \mathrm{~kJ} \mathrm{~d}^{-1} \mathrm{~kg}^{-0.75}$ ). Despite low DMI and a low-fibre diet (NDF $21 \pm 3 \%$ in dry matter), methane production accounted for $9.4 \pm 0.8 \%$ (2.7 \% in the fourth individual) of gross energy intake, which exceeds ruminant literature data on forage-only diets. These results corroborate literature reports on low DMI, DF, MR and long MRT in other sloth species. The long MRT are probably responsible for the comparatively high methane output, providing more opportunity for methanogenic archaea than in any other mammal to produce significant amounts of methane.
\end{abstract}

Key words: foregut, Pilosa, Folivora, digestibility, enteric methanogenesis

\section{Verdauungsphysiologie, Metabolismus und Methanproduktion bei Linnés Zweizehenfaultier (Choloepus didactylus)}

\section{Zusammenfassung}

Faultiere sind bekannt für niedrige Stoffwechsel (MR), Futteraufnahme und Kotabsatzfrequenz (DF). In einem zweiwöchigen Fütterungsversuch mit einer Standard-ZooRation und einer 24-h-Respirationsmessung untersuchten wir Verdauungsphysiologie und MR bei vier Individuen $(10.0 \pm 3.7 \mathrm{~kg})$ des kaum erforschten Linné's Zweifingerfaultiers (Choloepus didactylus). Die Trockensubstanzaufnahme (DMI), DF und PartikelRetentionszeit (MRT) betrugen $12 \pm 3 \mathrm{~g} \mathrm{~kg}^{-0.75} \mathrm{~d}^{-1}$, alle 5 Tage und $>140 \mathrm{~h}$ bei drei, aber $53 \mathrm{~g}$ $\mathrm{kg}^{-0.75} \mathrm{~d}^{-1}$, täglich und $82 \mathrm{~h}$ bei dem vierten Tier, das für einen früheren Gewichtsverlust kompensierte. Flüssigkeitsmarker wurden stets schneller ausgeschieden als Partikelmarker, was auf 'digesta washing' hinweist. Die anhand des $\mathrm{O}_{2}$-Verbrauchs gemessene MR stimmte mit der Aufnahme metabolischer Energie bei drei Tieren (173 \pm 22 vs. $168 \pm 44 \mathrm{~kJ} \mathrm{~d}^{-1} \mathrm{~kg}^{-0.75}$ ), nicht aber beim vierten Tier ( 225 vs. $698 \mathrm{~kJ} \mathrm{~d}^{-1} \mathrm{~kg}^{-0.75}$ ) überein. Trotz geringer DMI und geringem Fasergehalt (NDF $21 \pm 3 \%$ in Futtertrockensubstanz) betrug die $\mathrm{CH}_{4}$-Produktion 
$9.4 \pm 0.8 \%$ (2.7 \% beim vierten Tier) der Bruttoenergieaufnahme, was Literaturwerte für Wiederkäuer auf Raufutter übertrifft. Diese Ergebnisse bestätigen bei anderen Faultierspezies gemessene niedrige DMI, DF, MR und lange MRT. Letztere sind durch die Verlängerung der Fermentationszeit wahrscheinlich für die relativ hohe $\mathrm{CH}_{4}$-Produktion verantwortlich, da Archaea mehr Zeit als bei allen anderen Säugetieren zur Methanogenese bleibt.

Stichworte: Vormagen, Pilosa, Folivora, Verdaulichkeit, enterische Methanogenese 


\section{Digestive physiology, metabolism and methane production of}

\section{captive Linné's two-toed sloths (Choloepus didactylus)}

C. Vendl ${ }^{1}$, S. Frei ${ }^{1}$, M.T. Dittmann ${ }^{1,2}$, S. Furrer ${ }^{3}$, C. Osmann ${ }^{4}$, S. Ortmann ${ }^{5}$, A. Munn ${ }^{6}$, M. Kreuzer $^{2}$ and M. Clauss ${ }^{1}$

1 Clinic for Zoo Animals, Exotic Pets and Wildlife, Vetsuisse Faculty, University of Zurich, Zurich, Switzerland

2 ETH Zurich, Institute of Agricultural Sciences, Zurich, Switzerland

3 Zoo Zurich, Switzerland

4 Zoo Dortmund, Germany

5 Leibniz Institute for Zoo and Wildlife Research (IZW), Berlin, Germany

6 School of Biological Sciences, University of Wollongong, Wollongong, NSW, Australia

\section{Correspondence}

M. Clauss, Clinic for Zoo Animals, Exotic Pets and Wildlife, Vetsuisse Faculty, University of Zurich, Winterthurerstr. 260, 8057 Zurich, Switzerland. Tel: +41 44635 83 76; Fax: +41 44 63589 01; E-mail: mclauss@ @etclinics.uzh.ch

Running head: Sloth digestive physiology 


\section{Summary}

Sloths are renowned for their low metabolic rate, low food intake and low defecation frequency. We investigated factors of digestive physiology and energy metabolism in four captive individuals (mean body mass $10.0 \pm \mathrm{SD} 3.7 \mathrm{~kg}$ ) of a hitherto mostly unstudied sloth species, Linné's two-toed sloth (Choloepus didactylus), in a 2-week digestion recording and $23 \mathrm{~h}$ respiration experiment on animals fed a standard zoo diet of vegetables and starchy components. Dry matter intake, defecation frequency and particle mean retention time (MRT) in the gastrointestinal tract (GIT) were $12 \pm 3 \mathrm{~g} /\left(\mathrm{kg}^{0.75}\right.$. day), once every 5 days and $>140 \mathrm{~h}$ in three individuals, but $53 \mathrm{~g} /\left(\mathrm{kg}^{0.75}\right.$. day $)$, daily and $82 \mathrm{~h}$ in one individual that was apparently compensating for a period of weight loss prior to the experiment. In all animals, solute marker was eliminated at a faster rate than the particle marker, indicating 'digesta washing' in the sloths' GIT. The overall metabolic rate calculated from oxygen consumption matched the metabolisable energy intake in three individuals ( $173 \pm 22 \mathrm{vs.} 168 \pm 44 \mathrm{~kJ} /\left(\mathrm{kg}^{0.75}\right.$. day)) but not in the fourth one (225 vs. $698 \mathrm{~kJ} /\left(\mathrm{kg}^{0.75}\right.$. day)), supporting the interpretation that this animal was replenishing body stores. In spite of the low food intake and the low-fibre diet $(209 \pm 26 \mathrm{~g}$ neutral detergent fibre/kg dry matter), methane production was rather high accounting for $9.4 \pm 0.8 \%$ of gross energy intake $(2.7 \%$ in the fourth individual), which exceeded literature data for ruminants on forageonly diets. These results corroborate literature reports on low intake, low defecation frequency, low metabolic rate and long MRT in other sloth species. The long MRT are probably responsible for the comparatively high methane production, providing more opportunity for methanogenic archaea than in other non-ruminant mammals to produce significant amounts of methane.

Keywords: foregut, Xenarthra, Pilosa, Folivora, digestibility, acetoclastic archaea, enteric methanogenesis 


\section{Introduction}

Sloths are arboreal, folivorous foregut fermenters (Montgomery and Sunquist 1978; Langer 1988; Foley et al. 1995). They are known for their slow lifestyle and low metabolic rate. While three-toed sloths (Bradypus spp.) are usually considered very strict folivores, feeding on a limited range of tree species, and are more difficult to maintain in captivity, two-toed sloths (Choloepus spp.) usually have a broader diet that includes a larger variety of plant species, and are easier to maintain in captivity (Raines 2005; Vaughan et al. 2007). Goffart (1971) and McNab (1978) stated that the basal metabolic rates of Choloepus and Bradypus spp. are only 34-56\% of the value expected for an average mammal of comparable body mass. This low metabolism is matched by a low thyroid activity as compared with other eutherian mammals (Lemaire et al. 1969), along with comparatively low, and fluctuating body temperatures that range between 30.2 and $34.2{ }^{\circ} \mathrm{C}$ (Ozorio de Almeida and Branco de Fialho 1924; Montgomery and Sunquist 1978; Oliveira et al. 1980; Merrit 1985). However, depending on ambient temperature body temperature can even vary between 29.4 and $40.6{ }^{\circ} \mathrm{C}$ as recorded in six free-ranging individuals (Montgomery and Sunquist 1978).

The low metabolic rate of sloths has been linked to peculiarities of their digestive physiology, which is characterised by a voluminous foregut. The forestomach complex of sloths is mainly sacciform and nearly fills the entire abdominal cavity (Goffart 1971; Foley et al. 1995). Together with its contents (and with the rectum, see below), the mass of the sloth's foregut can amount to between 20 to $30 \%$ of the animal's body mass (Goffart 1971; Langer 1988). A low food intake (Montgomery and Sunquist 1975; Nagy and Montgomery 1980; Foley et al. 1995), low fermentation rates in the forestomach (Foley et al. 1995) and long digesta retention times (Montgomery and Sunquist 1978; Foley et al. 1995) have been documented. The rectum of sloths has been described as a 'pouch' (Foley et al. 1995) due to its large capacity and the fact that, in contrast to other mammals, faeces are stored at this site for several days. Thus, an evident peculiarity of the digestive physiology of sloths appears to be their low defecation frequency. Reported defecation intervals for sloths vary between 3.7 days for Choloepus didactylus (Eisenberg and Maliniak 1985) and 8-10 days for Bradypus spp. (Ozorio de Almeida and Branco de Fialho 1924; Montgomery and Sunquist 1975). Because defecation occurs so rarely, the amount voided at any one defecation event is often substantial. Ozorio de Almeida and 
Branco de Fialho (1924) described wet faeces weights of $250 \mathrm{~g}$ and up to $1200 \mathrm{ml}$ of urine in a single elimination event of a $3.7 \mathrm{~kg}$ animal, and illustrated this with a comparison to humans: If people voided the same volume as sloths relative to their body weight, a person weighing $70 \mathrm{~kg}$ would eliminate $27 \mathrm{~kg}$ of faeces and urine at a time.

The low defecation frequency of sloths corresponds to their long digesta retention times of 147 to $152 \mathrm{~h}$ (Foley et al. 1995). However, the latter data were not obtained from live animals, but collected following feeding of various markers to animals at different time intervals prior to euthanasia and dissection, in order to overcome the problem that, given the low defecation frequency, conventional retention time measurements are difficult to perform. The different markers used by Foley et al. (1995) were all applied in liquid form, under the assumption that some would tend to bind more to particulate matter than others. However, this assumption was not tested, and the authors themselves cautioned that their finding requires corroboration. In another study in which glass beads were fed to freeranging sloths even longer retention times were found (Montgomery and Sunquist 1978), but the comparability of the glass beads with natural digesta was not assessed.

A slow digesta passage rate would be expected to result in a very thorough fibre digestion, but data are scarce. To date, no digestibility measurements have been performed in captive sloths to our knowledge. Using manganese as an internal marker in free-ranging Bradypus feeding on leaves, Nagy and Montgomery (1980) determined an apparent dry matter digestibility of $64 \%$. Given that in captivity, sloths are often fed diets that do not contain leaves but cooked rice, fruits and vegetables (Merrit 1985), distinctively higher digestibilities may be expected for zoo animals. The extent to which the digestive processes in sloths resemble those in other herbivorous mammals remains uncertain. Although the microbial community in sloth faeces shows a degree of similarity to those of other herbivorous mammals, it is nevertheless distinct (Delsuc et al. 2014). For example, sloths apparently do not harbour ciliates in their stomach (Denis et al. 1967). Still, the faeces of captive sloths emitted a significant volume of methane (Hackstein and van Alen 1996), indicating the presence of methanogens in their digestive tract.

Therefore, to put comparisons of sloths with other herbivores on a broader basis, we determined the mean retention time of solutes and particles by feeding two different types of markers, and the 
digestibility of the diet, in captive two-toed sloths. We also recorded the resting metabolic rate via oxygen $\left(\mathrm{O}_{2}\right)$ consumption and the methane $\left(\mathrm{CH}_{4}\right)$ production via chamber respirometry in these animals. For the sloth species investigated, many measurements were recorded for the first time.

\section{Material and Methods}

The experiments took place under the Swiss Cantonal Animal Experiment Licence no. 142/2011. Four adult Linné's two-toed sloths (Choloepus didactylus) (designated as animals 1-4) from two zoological institutions were investigated with one male and one female per zoo. All four animals were kept individually to allow recording of food intake and faecal excretion. The animals were kept indoors at both facilities at ambient temperatures of $21-22{ }^{\circ} \mathrm{C}$. The study consisted of a 2 week adaption period, a collection period of 13 days, and finally $23 \mathrm{~h}$ of respiration measurements. During the entire study the animals were fed a diet of vegetables, rice and salad, where individual ingredients and their proportions were consistent within individuals but differed between the two zoos (Table 1). Sloths were fed once (zoo A) or twice per day (zoo B). Fresh water was available at all times.

In preparation for the present study, the proportion of fruits in the conventional zoo diet was reduced and that of vegetables increased over a period of approximately 4 weeks, in order to reduce the estimated overall sugar concentration of the zoo diet and hence make it more similar to the natural diet. This caused a marked temporary reduction in food intake in one animal (animal 4) with concomitant weight loss. Subsequently, this animal increased its food intake, and was still in this stage of - potentially compensatory - high food intake during the study (both adaptation and collection period), which resulted in notable deviations in the findings from those obtained in animals 1-3.

During the collection period, food intake was measured by weighing the food offered (each ingredient individually) and the leftovers at the next feeding time. Representative samples of every offered food ingredient (approx. $500 \mathrm{~g}$ per ingredient) were taken for analysis. Because sorting out individual ingredients from the leftovers proved difficult, and to be able to control for water loss, leftovers were always collected completely. Food samples and the complete leftovers were weighed and frozen at $-20{ }^{\circ} \mathrm{C}$. 
For the estimation of the mean retention time (MRT) of the digesta, we used cobalt (Co)-EDTA as solute marker for the fluid digesta component, and hay particles $(<2 \mathrm{~mm})$ mordanted with chromium (Cr) as particle marker. Co-EDTA and Cr-mordanted fibres were prepared according to Udén et al. (1980). The mordanted fibres contained $36.9 \mathrm{~g} \mathrm{Cr} / \mathrm{kg}$ DM. Markers were offered in the morning of the first day of the collection period. Sloths received on average $0.38 \mathrm{~g}( \pm \mathrm{SD} 0.02 \mathrm{~g})$ of Co-EDTA and $1.95 \mathrm{~g}( \pm 0.45 \mathrm{~g})$ of Cr-mordanted fibre as a pulse dose. Markers were offered with a small amount of cooked rice for $30 \mathrm{~min}$, during which all individuals consumed most of the markers, and then the residues were removed and replaced with the remainder of the daily food serving.

Prior to marker feeding, during the adaptation period, faecal samples were taken for assessing the background levels of Co and Cr. After marker feeding, faeces were weighed and collected completely after each defecation event during the entire collection period. The enclosures were checked for faeces at least twice a day: in the morning and the late afternoon. If possible, each defecation was separated into different segments corresponding to material retained in the rectum for longer, intermediate or shorter periods right after being collected. The basis for this separation was the observation that the faeces were mostly arranged in a vertical or semi-vertical posture, which reflected the position of the faeces in the rectum, with the part retained longest in the rectum at the bottom and the most recent part on top. The time interval represented by the defecation was divided equally among the individual portions of one defecation.

Diet ingredient samples, the complete leftovers, and faeces were dried at $60^{\circ} \mathrm{C}$ and ground through a $0.75 \mathrm{~mm}$ sieve with a centrifuge mill (Retsch GmbH, Haan, Germany). Standard nutrient analyses (AOAC 1995) were carried out, including the determination of contents of dry matter (DM) and total ash (AOAC no. 942.05), crude protein (CP, AOAC no. 977.02), ether extracts (EE, AOAC no. 963.15), crude fibre (CF, AOAC no. 978.10), neutral detergent fibre (NDFOM, AOAC no. 2002.04), acid detergent fibre and acid detergent lignin ( $\mathrm{ADF}_{\mathrm{OM}}$ and $\mathrm{ADL}, \mathrm{AOAC}$ no. 973.18). Gross energy (GE) was determined by bomb calorimetry (IKA-Calorimeter C4000, Ika, Stauffen, Germany). All fibre values were corrected for ash content. All analyses were performed in duplicate.

Marker analysis was performed in a similar way as in previous studies (Frei et al. 2015). For wet ashing samples were digested with $4 \mathrm{ml}$ nitric acid $\left(\mathrm{HNO}_{3}\right)$ and $2 \mathrm{ml}$ hydrogen peroxide in a 
microwave MLS ‘START 1500’ (MLS GmbH, Leutkich, Germany). Temperature was increased over $15 \mathrm{~min}$ to $170{ }^{\circ} \mathrm{C}$, and over $20 \mathrm{~min}$ to $200{ }^{\circ} \mathrm{C}$, then held at $200{ }^{\circ} \mathrm{C}$ for $5 \mathrm{~min}$. The wave length was $12.25 \mathrm{~cm}$ and the frequency $2.45 \mathrm{GHz}$. Determination of $\mathrm{Co}$ and $\mathrm{Cr}$ in the sample digests was performed using an inductively coupled plasma optical emission spectrometer (model Optima 8000, Perkin Elmer, Rodgau, Germany). Sample introduction was carried out by using a peristaltic pump connected to a Meinhard nebulizer with a cyclon spray chamber. The measured spectral element lines were: Co: $228.616 \mathrm{~nm}$; Cr: $267.716 \mathrm{~nm}$. The radio frequency power was set to $1400 \mathrm{~W}$, the plasma gas was $8 \mathrm{~L}$ argon $/ \mathrm{min}$, whereas the nebulizer gas was $0.6 \mathrm{~L}$ argon $/ \mathrm{min}$.

Nutrient intake was calculated as the amount of nutrients offered via the individual food ingredients minus the amount of nutrients remaining in the leftovers. The apparent digestibility (aD) of DM and nutrients was calculated as the percentage of the respective intake not eliminated via faeces (Robbins 1993). Digestible energy intake (DEI) was calculated as the GE intake (GEI) multiplied by aD GE; metabolisable energy intake (MEI) was estimated as $87 \%$ of DEI (Robbins 1993, for ruminants on concentrates). The MRT through the whole digestive tract was calculated by a standard method (Thielemans et al. 1978). Because marker excretion was evidently not complete in three out of four cases (see results), the calculated MRT are truncated and have to be considered underestimates. The total DM gut content (DMC, kg) was calculated according to Holleman and White (1989) using DM intake, $\mathrm{MRT}_{\text {particle }}$ and aD DM (Müller et al. 2013).

After the collection period, animals were weighed and placed in open circuit respiration chambers, each for a period of $23 \mathrm{~h}$. The chambers had a volume of $0.9 \mathrm{~m}^{3}$ (female, zoo A), $0.8 \mathrm{~m}^{3}$ (male, zoo A) and $0.6 \mathrm{~m}^{3}$ (zoo B), and were furnished with a wooden board and a climbing pole. A constant ambient temperature was provided at $21^{\circ} \mathrm{C}$ (zoo A) and $17{ }^{\circ} \mathrm{C}($ zoo B). Food (diet as described) and fresh water was placed into the chambers at the beginning of the measurements. Chambers were fitted with air inlets on the bottom and air outlets on the top of the box to ensure a constant airflow generated by a pump (Flowkit 100, Sable Systems, Las Vegas, USA). Out-flowing air was ducted via flexible hoses to a gas multiplexer, which allowed the simultaneous measurement of two individuals and baseline values from ambient air, at the interval of $60 \mathrm{~s}$ each. Concentrations of $\mathrm{O}_{2}$ and $\mathrm{CO}_{2}$ were analysed by a Turbofox (Sable Systems, Las Vegas, USA). Methane was measured by a 
MA-10 Methane Analyzer (Sable Systems). Data were adjusted for barometric pressure, water vapour pressure and air flow rates, which were constantly recorded during respirometry (Turbofox, Sable Systems). The airflow produced by the pumps averaged at $10.4 \pm 1.1 \mathrm{~L} / \mathrm{min}$. Gas analysers were manually calibrated with calibration gases (pure $\mathrm{N}_{2}$, and a mixture containing $19.91 \% \mathrm{O}_{2}, 0.5032 \%$ $\mathrm{CO}_{2}, 0.4945 \% \mathrm{CH}_{4}$ dissolved in $\mathrm{N}_{2}$ ). Data obtained by the respirometry system were analysed with the software ExpeData (Sable Systems) for $\mathrm{O}_{2}$ consumed and $\mathrm{CH}_{4}$ and $\mathrm{CO}_{2}$ emitted after correcting for gas concentrations in incoming air. The mean metabolic rate was calculated based on the entire $23 \mathrm{~h}$ measurement period, therefore accounting for the activity of the animals inside the box, while the resting metabolic rate of the animals was calculated by selecting the 20 lowest $\mathrm{O}_{2}$ measurements per individual within the entire measurement (adapted from Derno et al. 2005). Data from the first hour the animals spent inside the respiration chambers were neglected. In order to estimate metabolic rate we multiplied the amount of $\mathrm{O}_{2}$ consumed (in L/h) by $20.08 \mathrm{~kJ}$ (McNab 2008). Methane production was expressed in absolute values and in relation to DM intake (DMI), GEI, DEI and digestible NDFOM intake (dNDFi).

\section{Results}

Compared to the other three animals, the animal putatively regaining weight after the diet acclimatisation period ingested, on an as-fed basis, nearly three times the amount (Table 1). All animals selected a diet lower in $\mathrm{ADF}_{\mathrm{OM}}$ than the diet offered (Table 2), suggesting a certain feeding selectivity.

The DMI across all sloths in the present study averaged $22 \pm 20 \mathrm{~g} /\left(\mathrm{kg}^{0.75}\right.$. day) (Table 3). Animal 4 had a distinctively higher DMI than the other animals; without this outlier, average DMI of the remaining three animals was $12 \pm 3 \mathrm{~g} /\left(\mathrm{kg}^{0.75}\right.$. day $)$. While animal 4 defecated, on average, once per day, the other animals defecated on average once every five days (Table 3). The time of first particle marker appearance in the faeces (transit time) was 58-96 $\mathrm{h}$ in animals $1-3$ and $32.5 \mathrm{~h}$ in animal 4 . The passage marker elimination curves indicated that except for animal 4, the marker was not completely eliminated in the study period, and the respective calculated MRT and DMC are therefore drastic underestimates. Assuming from the marker elimination curves (Fig. 1) that complete MRT in animals 
1-3 are probably 2-3 times the calculated value, these three animals would have $\mathrm{MRT}_{\text {particle }}$ of a magnitude of 10-15 days, and DMC of about 3.3-5.3 \% of their body mass. Irrespective of the completeness of marker elimination, the elimination patterns indicate that in all four animals, the solute marker travels faster though the gut than the particle marker (Fig. 1).

The aD coefficients were mostly above $90 \%$, but were lower specifically for CP and EE (Table 3). DEI and MEI were higher in animal 4 than in the other animals (Table 3), and this animal also had the highest relative metabolic rate (Table 4). In the other three animals, MEI averaged at $168 \pm 44$ $\mathrm{kJ} /\left(\mathrm{kg}^{0.75}\right.$. day) (Table 3), which was very similar to the overall metabolic rate estimated via $\mathrm{O}_{2}$ consumption of $173 \pm 22 \mathrm{~kJ} /\left(\mathrm{kg}^{0.75}\right.$. day) (Table 4). The absolute amount of $\mathrm{CH}_{4}$ produced by animal 4 , as well as $\mathrm{CH}_{4}$ per $\mathrm{kg} \mathrm{BM}$, was similar to that in the other animals; in contrast, $\mathrm{CH}_{4}$ per unit DMI, GEI or dNDFi was distinctively lower in this animal (Table 4).

\section{Discussion}

The present study corroborates literature reports on the low food intake, low defecation frequency, low metabolic rate and long digesta retention times in sloths in general, while providing the corresponding data for a sloth species in which these traits have mostly not been investigated (C. didactylus), and also documenting hitherto unreported measures of digestiblity, energy intake, $\mathrm{CH}_{4}$ production and evidence for 'digesta washing'. Only four animals were investigated, and one of these animals deviated from the pattern observed in the others due to a - for sloths - exceptionally high food intake; the results of the other three animals were consistent between the study animals and also with literature on sloths.

\section{Zoo diets for sloths}

A major limitation of this study is the use of a diet of mixed vegetables, fruits, pelleted compounds, rice, potatoes and grains (Table 1); such a diet is typically fed to two-toed sloths in zoos (Merrit 1985). The natural diet of Choloepus contains a variety of plant material, including mainly leaves but also buds, flowers, twig tips and young stems (Merrit 1985; Vaughan et al. 2007) and also algae that grow in the sloths' own fur (Pauli et al. 2014). The claim that Choloepus also ingest animal material is 
apparently not based on observations in the wild but on experiences at zoos where individuals accept animal foods and eggs (Merrit 1985). When compared to leaves ingested by Bradypus with CP levels of $159 \mathrm{~g} / \mathrm{kg}$ DM and NDF and ADL of 391 and $140 \mathrm{~g} / \mathrm{kg} \mathrm{DM}$, respectively (Foley et al. 1995), the zoo diet (Table 2) was of similar protein but lower fibre content. The sloths themselves even increased this difference slightly by selecting against fibre content (Table 2).

In captivity, sloths often suffer from digestive diseases such as stasis, diarrhoea, dysbiosis, abdominal distension and rectal prolapse (de Stefani Munaó Diniz and Oliveira 1999; Aguilar and Superina 2015). Additionally, there is some evidence that in captivity, sloths are less active and sleep more than in the wild (Rattenborg et al. 2008; Hayssen 2011). It appears plausible that diets that are very high in starch and sugar components but low in fibre could contribute to the phenomena mentioned above, possibly by disrupting the forestomach microflora (Clauss and Dierenfeld 2008), by reducing the feeding activity required by the animals, by a lack of gut motility stimulation, and potentially also by leading to obesity in certain individuals. If this reasoning is correct, slowly adjusting the diet fed in captivity to fibre levels of natural diets and spreading it around the enclosure rather than offering it in one bowl could not only improve the health status, but also increase the activity of sloths displayed in captivity.

\section{Digestibility measurements}

One reason for the very high apparent digestibilities measured in the present study is probably the low fibre content of the diet, as is suggested when comparing the values with those measured in either freeranging three-toed sloths or foregut-fermenting primates (Fig. 2a) or a variety of vertebrate herbivores (Fig. 2b). Only the digestibility of CP, and in particular of EE (crude lipids), were lower. Low lipid digestibilities have been reported in other herbivores and are commonly interpreted as a consequence of the elimination of microbial matter which includes lipids (e.g. Clauss et al. 2003). The very long MRT in sloths, with prolonged storage of digesta in the rectum (Foley et al. 1995) where the presence of volatile fatty acids suggests microbial activity (Foley et al. 1995), probably leads to microbial growth and hence elimination of microbial protein and lipids, which in turn lead to an apparent reduction of the respective digestibility values. This is more pronounced if the respective nutrient is 
present at a lower concentration in the diet (Robbins 1993) - a fact evident in the lower aD EE of animals from facility 2 (Table 3), where dietary EE levels were particularly low (Table 2).

However, the high digestibility values need to be viewed with scepticism. On the one hand, the fact that passage markers were not excreted completely in three out of four animals (Fig. 1) could indicate that the faecal collection period was too short for a representative collection of faeces that allows digestibility calculations. On the other hand, the measured digestibility values were similarly high in animal 4 , in which the passage markers were well excreted within the collection period. Another possible reason for overestimated digestibilities could have been an increase in daily food intake over the course of the collection period, where the concomitant increase in faeces production was not recorded due to the delay by the long MRT, but daily intake data did not indicate such a trend (data not shown). Given that $\mathrm{NDF}_{\mathrm{OM}}$ contained $12.4 \pm 3.5 \%$ ADL (Table 2), which is considered indigestible, digestibility estimates for $\mathrm{NDF}_{\mathrm{OM}}$ of $92.1 \pm 2.5 \%$ (Table 3 ) are higher than the theoretically possible $87.6 \%$. While these data could suggest that, due to their extremely long MRT, sloths digest the digestible part of fibre completely, they also indicate that the factors of low dietary fibre (and in particular ADL) content and low defecation frequency might make accurate digestibility estimates very difficult. Ideally, the digestive capacity of sloths should be evaluated on diets higher in fibre, with both food intake and faeces production monitored on a daily basis for periods of 4-6 weeks.

\section{Food intake and defecation rate of sloths}

The only previous report on food intake in two-toed sloths is for $C$. hoffmanni fed a zoo diet, with a daily intake of 150-400 $\mathrm{g}$ as fed per adult animal (Merrit 1985); this corresponds to the as fed intake of 281-554 g by animals $1-3$ of our study. Given the higher fibre content and lower apparent digestibility of the diet of free-ranging Bradypus, one would expect the captive Choloepus of the present study to have an even lower DMI than the values of $20-22 \mathrm{~g} /\left(\mathrm{kg}^{0.75}\right.$. day) estimated for Bradypus on a natural diet (Nagy and Montgomery 1980; Foley et al. 1995). When excluding animal 4 with its apparently compensatory high food intake after its weight loss period, the DMI of the other three sloths of the present study matched this prediction at $12 \pm 3 \mathrm{~g} /\left(\mathrm{kg}^{0.75}\right.$. day $)$. The DMI of sloths is thus only a quarter to half of the mammalian herbivore average of $39-46 \mathrm{~g} /\left(\mathrm{kg}^{0.75}\right.$. day) (Müller et al. 2013). 
A consequence of the low food intake is the low defecation frequency, which resembled that previously documented for captive $C$. didactylus by Eisenberg and Maliniak (1985) of about once every 4 days. When comparing the defecation frequency of sloths with that of some other herbivores known for low defecation frequencies, such as rhinoceroses and tapirs (Fig. 3a), the low defecation frequencies of sloths appear simply as an effect of low food intake. However, higher defecation frequencies in other herbivore groups such as ruminants (e.g. Mitchell et al. 1985; Andersen et al. 1992), macropods (e.g. Johnson et al. 1987), primates (Lambert 2002), horses (Haenlein et al. 1966) or elephants (Wing and Buss 1970) are known, and cannot be explained by differences in assumed food intake between these groups. Factors that account for differences in defecation frequency between species beyond the mere influence of intake level are, to our knowledge, not explored. In sloths, the very low defecation frequency is linked to a peculiar, potentially costly and risky defecation behaviour that includes descent from trees to deposit the faeces directly on the ground (Montgomery and Sunquist 1975). Recently, it has been suggested that this behaviour supports a mutualistic relationship of sloths and moths that deposit their eggs in sloth faeces where larvae grow, while adult moths live in the fur of sloths and provide nutrients to algae that grow in the fur and are ingested by the sloths (Pauli et al. 2014). Alternative explanations suggested previously in the literature include olfactory communication (territory marking), fertilisation of preferred trees, and predator avoidance (Pauli et al. 2014).

\section{Digesta retention in sloths}

Few data exist on digesta passage in sloths. Using a barium test meal and subsequent x-rays, Britton (1941) found digesta to remain in the sloth's forestomach for 70-90 h. Montgomery and Sunquist (1978) fed glass beads with a diameter of $3 \mathrm{~mm}$ to free-ranging $B$. variegatus and observed that even after 50 days only $95 \%$ of the beads had been eliminated through the gastrointestinal tract. Foley et al. (1995) questioned these results, as they found accumulations of coarse particles of similar size as these glass beads in the prepyloric stomach of B. tridactylus, and stated that the majority of digesta particles is much smaller and passes through the gastrointestinal tract faster. Instead, they recorded a MRT of about $150 \mathrm{~h}$ for both liquid and solid digesta by administering various markers in liquid form, some of 
which they assumed to bind to particles. The incomplete (i.e., underestimated) MRT of animals 1-3 in the present study indicate a similar magnitude; only the MRT of animal 4, with its distinctively higher food intake, were shorter. Comparing MRT to defecation frequency in sloths, rhinos and tapirs (Fig. 3b) indicates that MRT in sloths are not caused by their low defecation frequency alone; most likely, this is additionally caused by their particularly voluminous digestive tracts (Goffart 1971; Langer 1988). This finding was confirmed in the present study. The gut contents of DM represent, on average, about 3\% of the body mass in herbivorous mammals (Müller et al. 2013). This value was as high as $6 \%$ in animal 4, the only animal with a complete MRT measurement, and estimated at 3.3-5.3\% in the other sloths.

Foley et al. (1995) suggested that fluid and particulate digesta phases move in parallel in the gastrointestinal tract of sloths, suggesting only limited 'digesta washing' (Müller et al. 2011). This conclusion was based on the finding that those liquid markers that were assumed to bind to particles moved through the gastrointestinal tract at the same rate as those liquid markers that usually do not. Based on these results, Schwarm et al. (2009) speculated that sloths might have a relatively low salivary flow rate, and that the sacciform forestomach of sloths might be less favourable for 'digesta washing' than the tubiform forestomach of macropods and hippopotamuses with their distinct difference in solute and particle MRT (Dellow 1982; Clauss et al. 2004). Although there is no distinct gradient in moisture content in the sloth's forestomach (Schwarm et al. 2013), these interpretations are challenged by the present results. Foley et al. (1995) conceded that in a future investigation, markers directly bound to particles should be used to corroborate their results, which was done in the present study. In doing so, we demonstrate that there is a distinct difference in the MRT of solute and particle markers. This indicates that, similar to many other herbivores including some nonruminant foregut fermenters (Müller et al. 2011), sloths use a strategy of 'digesta washing' where fluid washes through the particulate digesta plug. The main advantage of such a mechanism is currently assumed to lay in the harvest of very fine particle such as microbes from the digesta, which may enhance the efficiency of forestomach fermentation by increasing the yield of microbial protein and selecting for fastergrowing microbes (Müller et al. 2011). 


\section{Metabolic rates of sloths}

The metabolic rates measured in C. didactylus in the present study are well within the range of those previously measured in three other sloth species (Table 5), further supporting the statement that sloths have metabolic rates of only $34-56 \%$ of the value expected for an average mammal of comparable body mass (Goffart 1971; McNab 1978). These findings are supported by the corresponding low ad libitum energy intakes in three of the four individuals of the present study (Table 3). When comparing literature data in Table 5, it should be noted that none of the sources indicated that they had fasted their sloths for a period of time that would guarantee a post-absorptive state, and that given the large gastrointestinal volume and slow digesta passage also documented in the present study, such measures most likely do not conform to the strict definition of 'basal metabolic rate' (White and Seymour 2003; Clauss et al. 2008). Notably, even though they do not regulate their body temperature as strictly as most other mammals, sloths apparently do not reduce metabolic rate with decreasing environmental temperature to a point well below that used in the present study (McNab 1978).

Of our four individuals, the particularly low metabolic rates of animal 1 (Table 4) are interesting. At $15 \mathrm{~kg}$, this individual had a distinctively higher body mass than reported for free-ranging Choloepus (Silva and Downing 1995: 4-8 kg; Adam 1999: $6 \mathrm{~kg}$; Vogel et al. 1999: up to $11 \mathrm{~kg}$; Hayssen 2011: 4-9 kg). This could have been the consequence of the ad libitum feeding of an energydense diet, similar to the situation reported for another xenarthran with a low metabolic rate, the giant anteater (Myrmecophaga tridactyla) (Stahl et al. 2012). This individual may have had more adipose tissue stores than usual, leading to even lower metabolic rates per unit of metabolic body size.

\section{Methane production by sloths}

Within species, the production of $\mathrm{CH}_{4}$ is usually high in individuals with long MRT (e.g. Okine et al. 1989 in cattle; El Oufir et al. 1996 in man; Goopy et al. 2014 in sheep). Similarly, in the sloth with the shortest MRT (animal 4), less $\mathrm{CH}_{4}$ was produced per unit energy and digestible fibre intake than in the other animals. However, the general magnitude of methanogenesis in the sloths of the present study was astonishing. The absolute daily $\mathrm{CH}_{4}$ production in $C$. didactylus was higher than expected for nonruminant herbivores of similar body mass (Fig. 4a). For the only other group of nonruminant 
forgut fermenters investigated so far (various macropodid marsupial species), there was no difference in $\mathrm{CH}_{4}$ ouput as compared with hindgut fermenters (Franz et al. 2011c; Madsen and Bertelsen 2012). As such, the high $\mathrm{CH}_{4}$ output of the investigated sloths result is surprising for two reasons: Firstly, in camelids, a low food intake due to a low metabolic rate (Dittmann et al. 2014a) is linked to a correspondingly lower $\mathrm{CH}_{4}$ production compared to similar-sized ruminants (Dittmann et al. 2014b). Hence, given the extremely low food intake levels in sloths, a much lower $\mathrm{CH}_{4}$ production was expected. Secondly, low dietary fibre levels are usually associated with a low $\mathrm{CH}_{4}$ production (Blaxter and Clapperton 1965). The sloths' diets in the present study contained 180-240 $\mathrm{g} \mathrm{NDF} / \mathrm{OM} / \mathrm{kg} \mathrm{DM}$, in contrast to $580-640 \mathrm{~g} / \mathrm{kg}$ in the other mammals used for comparison in Figure 4. At 9.4\% of total GEI in animals 1-3, $\mathrm{CH}_{4}$ production in relation to energy intake was distinctively higher than the $5.5-6.5 \%$ of GEI usually assumed for ruminants (Johnson and Ward 1996). Only animal 4 was, at $2.5 \%$ of GEI, below these levels, but still higher than other nonruminant herbivores (Fig. 4b). A similar pattern was evident when expressing $\mathrm{CH}_{4}$ production per unit digestible fibre intake (Fig. 4c). Given these findings, it appears reasonable to interpret the high $\mathrm{CH}_{4}$ levels measured in the present study as a consequence of the particularly long MRT in sloths.

Different groups of methanogens (archaea) either utilize $\mathrm{H}_{2}$ (and $\mathrm{CO}_{2}$ ), formiate or even acetate for methanogenesis (Thauer et al. 2008). The removal of $\mathrm{H}_{2}$ from the fermentation system is necessary to maintain concentration gradients that favour the fermentative process (Van Soest 1994). In contrast, in herbivores that rely on microbial fermentation of plant fibre (the most important product of which is acetate, Stevens and Hume 1998), the conversion of acetate to $\mathrm{CH}_{4}$ would represent a potentially prohibitive loss of one of their major sources of energy. Bryant (1979) suggested that acetoclastic archaea do not occur in animal guts because of their low growth rates that are longer than commonly observed digesta retention times, an opinion also expressed by Miller and Wolin (1986). Based on this information, Van Soest (1994) postulated that herbivores relying on microbial fermentation cannot have MRT longer than $96 \mathrm{~h}$, because otherwise the acetoclastic achaea, with a generation interval of 4 days, could cause these severe energy losses. The fact that some herbivores with microbial fermentation, such as the sloths of our study or tortoises (Franz et al. 2011a) have MRT well beyond $96 \mathrm{~h}$ indicates that this should not be considered a fixed constraint, but nevertheless raises the question 
whether the $\mathrm{CH}_{4}$ evidently produced by sloths (this study) or tortoises (Franz et al. 2011b) could at least partially stem from acetoclastic archaea. Although the claim of a 4 day growth rate is difficult to corroborate in the literature, there is not only evidence for lower growth rates, but also for an affiliation for lower temperatures in acetoclastic archaea (Thauer et al. 2008), which would again match conditions in tortoises and sloths with their comparatively low body temperatures. Thus, we speculate that the particularly high $\mathrm{CH}_{4}$ production in sloths could be a consequence of not only $\mathrm{H}_{2-}$ utilising methanogenesis but, additionally, of acetoclastic methanogenesis, for example in the rectum. Because acetoclastic archaea are the main component of biogas fermenters, a comparison of archaeal composition in other herbivores, sloths, tortoises and biogas fermenters would be interesting.

\section{Acknowledgments}

We thank Ilona Offhaus, Daniel Schöneberg and Alfred Sidler for support in animal management, and Heidrun Barleben and Carmen Kunz, Muna Merghani and Elisabeth Wenk for sample analysis, and two anonymous reviewers for their constructive comments. This study was part of project 310030_135252/1 funded by the Swiss National Science Foundation.

\section{Literature}

Adam, P.J., 1999: Choloepus didactylus. Mammalian Species 621, 1-8.

Aguilar, R.F.; Superina, M., 2015: Xenarthra, In: Miller, R.E.; Fowler, M.E. (eds.), Fowler's zoo and wild animal medicine. Elsevier Saunders, St. Louis. 355-369.

Andersen, R.; Hjeljord, O.; Sæther, B.E., 1992: Moose defecation rates in relation to habitat quality. Alces 28, 95-100.

AOAC, 1995: Official methods of analysis of AOAC International. Association of Official Analytical Chemists, Arlington VA.

Blaxter, K.L.; Clapperton, J.L., 1965: Prediction of the amount of methane produced by ruminants. British Journal of Nutrition 19, 511-522.

Britton, S.W., 1941: Function and form in the sloth. Quarterly Review of Biology 16, 13-34, 190-207. Bryant, M.P., 1979: Microbial methane production - theoretical aspects. Journal of Animal Science 48, 193-201.

Clauss, M.; Löhlein, W.; Kienzle, E.; Wiesner, H., 2003: Studies on feed digestibilities in captive Asian elephants (Elephas maximus). Journal of Animal Physiology and Animal Nutrition 87, 160173.

Clauss, M.; Schwarm, A.; Ortmann, S.; Alber, D.; Flach, E.J.; Kühne, R.; Hummel, J.; Streich, W.J.; Hofer, H., 2004: Intake, ingesta retention, particle size distribution and digestibility in the hippopotamidae. Comparative Biochemistry and Physiology A 139, 449-459.

Clauss, M.; Dierenfeld, E.S., 2008: The nutrition of browsers, In: Fowler, M.E.; Miller, R.E. (eds.), Zoo and wild animal medicine. Current therapy 6. Saunders Elsevier, St. Louis. 444-454. 
Clauss, M.; Hummel, J.; Streich, W.J.; Südekum, K.-H., 2008: Mammalian metabolic rate scaling to 2/3 or 3/4 depends on the presence of gut contents. Evolutionary Ecology Research 10, 153-154.

Clauss, M.; Lang-Deuerling, S.; Müller, D.W.H.; Kienzle, E.; Steuer, P.; Hummel, J., 2010: Retention of fluid and particles in captive tapirs (Tapirus spp.). Comparative Biochemistry and Physiology A 157, 95-101.

de Stefani Munaó Diniz, L.; Oliveira, P.M., 1999: Clinical problems of sloths (Bradypus sp. and Choloepus sp.) in captivity. Journal of Zoo and Wildlife Medicine 30, 76-80.

Dellow, D.W., 1982: Studies on the nutrition of macropodine marsupials. III. The flow of digesta through the stomach and intestine of macropodines and sheep. Australian Journal of Zoology 30 , 399-406.

Delsuc, F.; Metcalf, J.L.; Wegener Parfrey, L.; Song, S.J.; Gonzales, A.; Knight, R., 2014: Convergence of gut microbiomes in myrmecophagous mammals. Molecular Ecology 23, 13011317.

Denis, C.; Jeuniaux, C.; Gerebtzoff, M.A.; Goffart, M., 1967: La digestion stomacale chez un paresseux: l'unau Choloepus hoffmanni Peters. Annales de la Societe Royale Zoologique de Belgique 97, 9-29.

Derno, M.; Jentsch, W.; Schweigel, M.; Kuhla, S.; Metges, C.C.; Matthes, H.D., 2005: Measurements of heat production for estimation of maintenance energy requirements of Hereford steers. Journal of Animal Science 83, 2590-2597.

Dittmann, M.T.; Hummel, J.; Runge, U.; Galeffi, C.; Kreuzer, M.; Clauss , M., 2014a: Characterising an artiodactyl family inhabiting arid habitats by its metabolism: low metabolism and maintenance requirements in camelids. Journal of Arid Environments 107, 41-48.

Dittmann, M.T.; Runge, U.; Lang, R.A.; Moser, D.; Galeffi, C.; Kreuzer, M.; Clauss, M., 2014b: Methane emission by camelids. PLoS One 9, e94363.

Eisenberg, J.F.; Maliniak, E., 1985: Maintenance and reproduction of two-toed sloth (Choloepus didactylus) in captivity, In: Montgomery, G.G. (ed.), The evolution and ecology of armadillos, sloths, and vermilinguas. Smithsonian Institution Press, Washington. 327-331.

El Oufir, L.; Bruley des Varannes, S.; Barry, J.L.; Cloarec, D.; Bornet, F.; Galmiche, J.P., 1996: Relations between transit time, fermentation products, and hydrogen consuming flora in healthy humans. Gut 38, 870-877.

Foley, W.J.; von Engelhardt, W.; Charles-Dominique, P., 1995: The passage of digesta, particle size, and in vitro fermentation rate in the three-toed sloth Bradypus tridactylus (Edentata: Bradypodidae). Journal of Zoology 236, 681-696.

Franz, R.; Soliva, C.R.; Kreuzer, M.; Steuer, P.; Hummel, J.; Clauss, M., 2010: Methane production and body mass in ruminants and equids. Evolutionary Ecology Research 12, 727-738.

Franz, R.; Hummel, J.; Müller, D.W.H.; Bauert, M.; Hatt, J.-M.; Clauss, M., 2011a: Herbivorous reptiles and body mass: effects on food intake, digesta retention, digestibility and gut capacity, and a comparison with mammals. Comparative Biochemistry and Physiology A 158, 94-101.

Franz, R.; Soliva, C.R.; Kreuzer, M.; Hatt, J.-M.; Furrer, S.; Hummel, J.; Clauss, M., 2011b: Methane output of tortoises: its contribution to energy loss related to herbivore body mass. PLoS One 6 , e17628.

Franz, R.; Soliva, C.R.; Kreuzer, M.; Hummel, J.; Clauss, M., 2011c: Methane in rabbits (Oryctolagus cuniculus) and guinea pigs (Cavia porcellus) on a hay-only diet: implications for the scaling of methane procution with body mass in nonruminant mammalian herbivores. Comparative Biochemistry and Physiology A 158, 177-181.

Frei, S.; Ortmann, S.; Reutlinger, C.; Kreuzer, M.; Hatt, J.-M.; Clauss, M., 2015: Comparative digesta retention patterns in ratites. The Auk: Ornithological Advances 132, 119-131.

Goffart, M., 1971: Function and form in the sloth. Pergamon Press, Oxford.

Goopy, J.P.; Donaldson, A.; Hegarty, R.S.; Vercoe, P.E.; Haynes, F.; Barnett, M.; Oddy, V.H., 2014: Low-methane yield sheep have smaller rumens and shorter rumen retention time. British Journal of Nutrition 111, 578-585.

Hackstein, J.H.P.; van Alen, T.A., 1996: Fecal methanogens and vertebrate evolution. Evolution 50, 559-572.

Haenlein, G.F.W.; Smith, R.C.; Yoon, Y.M., 1966: Determination of the fecal excretion rate of horses with chromic oxide. Journal of Animal Science 25, 1091-1095. 
Hatt, J.-M.; Clauss, M.; Gisler, R.; Liesegang, A.; Wanner, M., 2005: Fiber digestibility in juvenile captive Galapagos tortoises (Geochelone nigra) and implications for the development of captive animals. Zoo Biology 24, 185-191.

Hayssen, V., 2011: Choloepus hoffmanni (Pilosa: Megalonychidae). Mammalian Species 43, 37-55.

Holleman, D.F.; White, R.G., 1989: Determination of digesta fill and passage rate from non absorbed particulate phase markers using the single dosing method. Canadian Journal of Zoology 67, 488494.

Irving, L.; Scholander, P.F.; Grinnel, S.W., 1942: Experimental studies of the respiration of sloths. Journal of Cellular and Comparative Physiology 20, 189-210.

Johnson, C.N.; Jarman, P.J.; Southwell, C.J., 1987: Macropod studies at Wallaby Creek. 5. Patterns of defecation by eastern gray kangaroos and red-necked wallabies. Wildlife Research 14, 133-138.

Johnson, D.E.; Ward, G.M., 1996: Estimates of animal methane emissions. Environmental Monitoring and Assessment 42, 133-141.

Lambert, J.E., 2002: Digestive retention times in forest guenons (Cercopithecus spp.) with reference to chimpanzees (Pan troglotydes). International Journal of Primatology 23, 1169-1185.

Langer, P. (ed.), 1988: The mammalian herbivore stomach. Gustav Fischer Verlag, Stuttgart/New York.

Lemaire, M.; Goffart, M.; Closon, J.; Winand, R., 1969: La fonction thyroidienne chez l'unau (Choloepus hoffmanny Peters). General and Comparative Endocrinology 12, 181-199.

Madsen, J.; Bertelsen, M.F., 2012: Methane production by red-necked wallabies (Macropus rufogriseus). Journal of Animal Science 90, 1364-1370.

McNab, B.K., 1978: Energetics of arboreal folivores: physiological problems and ecological consequences of feeding on ubiquitous food supply, In: Montgomery, G.G. (ed.), The ecology of arboreal folivores. Washington: Smithsonian Institution Press. 153-162.

McNab, B.K., 2008: An analysis of the factors that influence the level and scaling of mammalian BMR. Comparative Biochemistry and Physiology A 151, 5-28.

Merrit, D.A., 1985: The two-toed sloth, Choloepus hoffmanni Peters, In: Montgomery, G.G. (ed.), The evolution and ecology of armadillos, sloths and vermilinguas. Smithsonian Institution Press, Washington and London. 333-341.

Miller, T.L.; Wolin, M.J., 1986: Methanogens human and animal intestinal tracts. Systematic and Applied Microbiology 7, 223-229.

Mitchell, B.; Rowe, J.J.; Ratcliffe, P.; Hinge, M., 1985: Defecation frequency in roe deer (Capreolus capreolus) in relation to the accumulation rates of faecal deposits. Journal of Zoology 207, 1-7.

Montgomery, G.G.; Sunquist, M.E., 1975: Impact of sloths on neotropical energy flow and nutrient cycling, In: Golley, F.B.; Medina, E. (eds.), Tropical ecological systems: trends in terrestrial and aquatic research. Springer-Verlag, New York. 69-98.

Montgomery, G.G.; Sunquist, M.E., 1978: Habitat selection and use by two-toed and three-toed sloths, In: Montgomery, G.G. (ed.), The ecology of arboreal folivores. Smithsonian Institution Press, Washington. 329-359.

Müller, D.W.H.; Caton, J.; Codron, D.; Schwarm, A.; Lentle, R.; Streich, W.J.; Hummel, J.; Clauss, M., 2011: Phylogenetic constraints on digesta separation: variation in fluid throughput in the digestive tract in mammalian herbivores. Comparative Biochemistry and Physiology A 160, $207-$ 220.

Müller, D.W.H.; Codron, D.; Meloro, C.; Munn, A.; Schwarm, A.; Hummel, J.; Clauss, M., 2013: Assessing the Jarman-Bell Principle: scaling of intake, digestibility, retention time and gut fill with body mass in mammalian herbivores. Comparative Biochemistry and Physiology A 164, 129-140.

Nagy, K.A.; Montgomery, G.G., 1980: Field metabolic rate, water flux and food consumption in threetoed sloths (Bradypus variegatus). Journal of Mammalogy 61, 465-472.

Nijboer, J.; Clauss, M., 2006: The digestive physiology of colobine primates, Fibre intake and faeces quality in leaf-eating monkeys. University of Utrecht, The Netherlands. 9-28.

Okine, E.K.; Mathison, G.W.; Hardin, R.T., 1989: Effects of changes in frequency of reticular contractions on fluid and particulate passage rates in cattle. Journal of Animal Science 67, 33883396.

Oliveira, L.H.A.; Da Costa, C.P.; Huggins, S.E., 1980: Cardiac mass, blood temperature and ventricular fibrillation: a study of the comparative physiology of the three-toed sloth and the domestic cat. Comparative Biochemistry and Physiology A 67, 483-490. 
Ozorio de Almeida, M.; Branco de Fialho, A., 1924: Métabolisme, température et quelques autres déterminations physiologiques faites sur le paresseux (Bradypus tridactylus). Comptes Rendus Des Seances De La Societe De Biologie Et De Ses Filiales 91, 1124-1125.

Pauli, J.N.; Mendoza, J.E.; Steffan, S.A.; Carey, C.C.; Weimer, P.J.; Peery, M.Z., 2014: A syndrome of mutualism reinforces the lifestyle of a sloth. Proceedings of the Royal Society B 281, 20133006.

Raines, J., 2005: Captive health and husbandry of the Bradypodidae. Zoo Biology 24, 557-568.

Rattenborg, N.C.; Voirin, B.; Vyssotski, A.L.; Kays, R.W.; Spoelstra, K.; Kuemmeth, F.; Heidrich, W.; Wikelski, M., 2008: Sleeping outside the box: electroencephalographic measures of sleep in sloths inhabiting a rainforest. biology letters 4, 402-405.

Robbins, C.T., 1993: Wildlife feeding and nutrition. Academic Press, San Diego.

Schwarm, A.; Ortmann, S.; Wolf, C.; Streich, W.J.; Clauss, M., 2009: Passage marker excretion in red kangaroo (Macropus rufus), collared peccary (Pecari tajacu) and colobine monkeys (Colobus angolensis, C. polykomos, Trachypithecus johnii). Journal of Experimental Zoology A 311, 647661.

Schwarm, A.; Ortmann, S.; Fritz, J.; Rietschel, W.; Flach, E.J.; Clauss, M., 2013: No distinct stratification of ingesta particles and no distinct moisture gradient in the forestomach of nonruminants: the wallaby, peccary, hippopotamus, and sloth. Mammalian Biology 78, 412-421.

Silva, M.; Downing, J.A., 1995: CRC handbook of mammalian body masses. CRC Press, Bota Racon.

Stahl, M.; Osmann, C.; Ortmann, S.; Kreuzer, M.; Hatt, J.-M.; Clauss, M., 2012: Energy intake for maintenance in a mammal with a low basal metabolism, the Giant anteater (Myrmecophaga tridactyla). Journal of Animal Physiology and Animal Nutrition 96, 818-824.

Stevens, C.E.; Hume, I.D., 1998: Contributions of microbes in vertebrate gastrointestinal tract to production and conservation of nutrients. Physiological Reviews 78, 393-427.

Thauer, R.K.; Kaster, A.K.; Seedorf, H.; Buckel, W.; Hedderich, R., 2008: Methanogenic archaea: ecologically relevant differences in energy conservation. Nature Reviews Microbiology 6, 579-591.

Thielemans, M.F.; Francois, E.; Bodart, C.; Thewis, A., 1978: Mesure du transit gastrointestinal chez le porc a l'aide des radiolanthanides. Comparaison avec le mouton. Annales De Biologie Animale, Biochimie, Biophysique 18, 237-247.

Udén, P.; Colucci, P.E.; Van Soest, P.J., 1980: Investigation of chromium, cerium and cobalt as markers in digesta. Rate of passage studies. Journal of the Science of Food and Agriculture 31, 625-632.

Van Soest, P.J., 1994: Nutritional ecology of the ruminant. 2nd edn. Cornell University Press, Ithaca.

Vaughan, C.; Ramírez, O.; Herrera, G.; Guries, R., 2007: Spatial ecology and conservation of two sloth species in a cacao landscape in Limón, Costa Rica. Biodiversity and Conservation 16, 2293 2310.

Vogel, I.; Vié, J.C.; de Thoisy, B.; Moreau, B., 1999: Hematological and serum chemistry profiles of free-ranging southern two-toed sloths in French Guiana. Journal of Wildlife Diseases 35, 531-535.

White, C.R.; Seymour, R.S., 2003: Mammalian basal metabolic rate is proportional to body mass ${ }^{2 / 3}$. Proceedings of the National Academy of Sciences of the USA 100, 4046-4049.

Wing, L.D.; Buss, I.O., 1970: Elephants and forests. Wildlife Monographs 19, 3-92. 


\section{Figure legends}

Fig. 1. Marker elimination patterns for solute matter (Co) and $2 \mathrm{~mm}$ particles $(\mathrm{Cr})$ in the sloths of the present study.

Fig. 2. a) Apparent digestibility of dry matter ( $\mathrm{aD} \mathrm{DM})$ as a function of dietary neutral detergent fibre (NDF) concentration in (i) the two-toed sloths (Choloepus didactylus) of the present study, (ii) freeranging three-toed sloths (Bradypus variegatus) (from Nagy and Montgomery 1980) and (iii) colobine monkeys (collected in Nijboer and Clauss 2006); b) aD DM as a function of dietary crude fibre concentration in comparison between sloths of the present study and several other vertebrate species (Equus ferus caballus, Geochelone nigra, Rhinoceros unicornis, Elephas maximus) (taken from Hatt et al. 2005).

Fig. 3. a) Defecation frequency as a function of dry matter intake relative to metabolic body mass (rDMI) and b) mean retention time (MRT) of particles as a function of defecation frequency in the two-toed sloths (Choloepus didactylus) (present study) compared to tapirs (Tapirus terrestris, Tapirus indicus), black rhinos (Diceros bicornis) and white rhinos (Ceratotherium simum) (from Clauss et al. 2010).

Fig. 4. Methane production of the individual sloths (open circles) relative to their body mass as a) absolute amount per day, b) proportion of gross energy intake (GEI), c) per unit digestible fibre intake (dNDFi) in comparison to ruminants (black regression line, Franz et al. 2010) and nonruminant mammalian herbivores (gray regression line, Franz et al. 2011c). 
Table 1 Diet incl. concentration of ingredients offered to the two-toed sloths (Choloepus didactylus) during the faecal collection period of 13 days

\begin{tabular}{|c|c|c|c|c|}
\hline Individual & 1 (male) & 2 (female) & 3 (female) & 4 (male) \\
\hline \multicolumn{5}{|c|}{ Food offered (g dry matter/day) } \\
\hline Apple & - & - & 15 & 16 \\
\hline Beetroot & 11 & 11 & 8 & 123 \\
\hline Broccoli & - & - & 15 & 16 \\
\hline Cabbage & 5 & 5 & - & - \\
\hline Carrots & 6 & 6 & - & - \\
\hline Celery & 3 & 1 & 12 & 14 \\
\hline Chard & 3 & 3 & - & - \\
\hline Chicory & - & - & 7 & 7 \\
\hline Cooked potato & 11 & 11 & 15 & 17 \\
\hline Cooked rice & 6 & 6 & 24 & 24 \\
\hline Cucumber & 2 & 2 & 5 & 5 \\
\hline Fennel & 3 & 3 & 5 & 5 \\
\hline Folivore pellets* & 51 & 51 & - & - \\
\hline Leek & 1 & 1 & - & - \\
\hline Lettuce & - & - & 6 & 5 \\
\hline Mache & - & - & 14 & 15 \\
\hline Onion & 3 & 3 & - & - \\
\hline Pepper & 3 & 3 & - & - \\
\hline String beans & 5 & 5 & - & - \\
\hline Tomato & 2 & 2 & - & - \\
\hline Wheat, soaked in water & 23 & 23 & - & - \\
\hline Zucchini & - & - & 10 & 11 \\
\hline No. of ingredients & 16 & 16 & 12 & 12 \\
\hline Total amount offered/day & 136 & 135 & 135 & 258 \\
\hline Total amount leftover/day & 73 & 53 & 63 & 50 \\
\hline
\end{tabular}

"Folivore pellets: "Blattfresser Pellets", $\mathrm{g} \mathrm{kg}^{-1}$ as fed: crude protein, 215; crude fibre, 90; total ash, 80; ether extract, 40. Producer: Michael Hassel GmbH, Langenargen, Germany. 
Table 2 Concentration of nutrients ( $\mathrm{g} / \mathrm{kg}$ dry matter unless indicated differently) in the diets ingested by two-toed sloths (Choloepus didactylus) in the present study

\begin{tabular}{lcccc}
\hline Individual & 1 & 2 & 3 & 4 \\
\hline Diet as offered: & & & & \\
Dry matter (g/kg as fed) & 189 & 192 & 91 & 92 \\
Total ash & 76 & 76 & 123 & 122 \\
Crude protein & 169 & 169 & 157 & 185 \\
Ether extract & 12 & 12 & 9 & 6 \\
Crude fibre & 75 & 76 & 75 & 76 \\
Neutral detergent fibre & 206 & 207 & 227 & 211 \\
Acid detergent fibre & 109 & 109 & 126 & 113 \\
Acid detergent lignin & 26 & 25 & 26 & 21 \\
Gross energy (kJ/g dry matter) & 17.8 & 17.8 & 16.7 & 16.6 \\
& & & & \\
Ingested diet: & & & & \\
Dry matter (g/kg as fed) & 225 & 182 & 129 & 91 \\
Total ash & 72 & 76 & 122 & 127 \\
Crude protein & 144 & 153 & 114 & 185 \\
Ether extract & 10 & 12 & 4 & 5 \\
Crude fibre & 59 & 71 & 38 & 74 \\
Neutral detergent fibre & 184 & 194 & 243 & 214 \\
Acid detergent fibre & 79 & 98 & 83 & 103 \\
Acid detergent lignin & 29 & 29 & 23 & 20 \\
Gross energy (kJ/g dry matter) & 18.0 & 17.9 & 15.5 & 16.4 \\
\hline
\end{tabular}


Table 3 Body mass, food intake, defecation frequency, mean retention time (MRT), digestibility and gut fill of two-toed sloths (Choloepus didactylus) in the present study

\begin{tabular}{|c|c|c|c|c|}
\hline Individual & 1 & 2 & 3 & 4 \\
\hline Body mass (kg) & 15.0 & 10.0 & 8.8 & 6.3 \\
\hline \multicolumn{5}{|l|}{ Dry matter intake } \\
\hline g/day & 63.2 & 81.5 & 71.5 & 208.4 \\
\hline $\mathrm{g} /\left(\mathrm{kg}^{0.75} \cdot\right.$ day $)$ & 8 & 14 & 14 & 53 \\
\hline \multicolumn{5}{|l|}{ Dry matter excretion } \\
\hline g/day & 2.2 & 5.4 & 3.5 & 11.7 \\
\hline $\mathrm{g} /\left(\mathrm{kg}^{0.75} \cdot\right.$ day $)$ & 0.28 & 0.96 & 0.69 & 2.96 \\
\hline Defecations (n/day) & 0.38 & 0.15 & 0.15 & 1.00 \\
\hline Fecal dry matter $(\mathrm{g} / \mathrm{kg})$ & 229 & 302 & 413 & 324 \\
\hline \multicolumn{5}{|l|}{ Mean retention time $(\mathrm{h})$} \\
\hline Solutes (Co) & $115^{\dagger}$ & $84^{\dagger}$ & $104^{\dagger}$ & 56 \\
\hline $2 \mathrm{~mm}$ particles $(\mathrm{Cr})$ & $120^{\dagger}$ & $142^{\dagger}$ & $150^{\dagger}$ & 82 \\
\hline \multicolumn{5}{|l|}{ Apparent digestibility (\%) } \\
\hline Dry matter & 96.6 & 93.4 & 95.1 & 94.4 \\
\hline Crude protein & 92.3 & 84.9 & 82.7 & 88.0 \\
\hline Ether extract & 85.8 & 79.7 & 22.5 & 27.1 \\
\hline Neutral detergent fibre & 91.6 & 89.1 & 95.2 & 92.3 \\
\hline Crude fibre & 93.1 & 89.9 & 88.7 & 95.0 \\
\hline Digestible energy intake $\left(\mathrm{kJ} /\left(\mathrm{kg}^{0.75} \cdot\right.\right.$ day $\left.)\right)$ & 140.0 & 239.3 & 201.0 & 802.3 \\
\hline Metabolisable energy intake $\left(\mathrm{kJ} /\left(\mathrm{kg}^{0.75} \cdot \text { day }\right)\right)^{\ddagger}$ & 121.8 & 208.2 & 174.8 & 698.0 \\
\hline \multicolumn{5}{|l|}{ Dry matter gut content ${ }^{\S}$} \\
\hline $\mathrm{kg}$ & $0.16^{\dagger}$ & $0.26^{\dagger}$ & $0.23^{\dagger}$ & 0.38 \\
\hline$\%$ of body mass & $1.1^{\dagger}$ & $2.6^{\dagger}$ & $2.7^{\dagger}$ & 6.0 \\
\hline
\end{tabular}

"ratio of $\mathrm{MRT}_{\text {particles }}$ to $\mathrm{MRT}_{\text {solutes }}$.

${ }^{\dagger}$ Marker excretion not finished within the study period; calculated MRT and gut content values therefore represent underestimates.

Calculated as 0.87 DEI.

${ }^{\S}$ Estimated according to Holleman and White (1989) based on food intake, digesta retention and digestibility. 
Table 4 Consumption of $\mathrm{O}_{2}$ and excretion of $\mathrm{CO}_{2}$ and $\mathrm{CH}_{4}$ in two-toed sloths (Choloepus didactylus) in the present study

\begin{tabular}{llcccc}
\hline Individual & & 1 & 2 & 3 & 4 \\
\hline $\mathrm{O}_{2}$ & $\mathrm{~L} /$ day & 57.6 & 54.9 & 43.7 & 44.5 \\
Metabolic rate & $\mathrm{kJ} /\left(\mathrm{kg}^{0.75} \cdot\right.$ day $)$ & 152 & 196 & 172 & 226 \\
Resting metabolic rate & $\mathrm{kJ} /\left(\mathrm{kg}^{0.75} \cdot\right.$ day $)$ & 98 & 151 & 131 & 159 \\
$\mathrm{CO}_{2}$ & $\mathrm{~L} /$ day & 48.8 & 51.1 & 43.5 & 44.7 \\
Respiratory quotient $^{*}$ & & 0.84 & 0.93 & 0.99 & 1.00 \\
Methane & $\mathrm{L} /$ day & 2.89 & 3.15 & 2.66 & 2.17 \\
& $\mathrm{~L} /(\mathrm{kg} \cdot$ day) & 0.19 & 0.32 & 0.30 & 0.35 \\
& $\mathrm{~L} / \mathrm{kg}$ dry matter intake & 45.8 & 38.7 & 37.2 & 10.4 \\
& \% of gross energy intake & 10.08 & 8.57 & 9.51 & 2.51 \\
& \% of digestible energy intake & 10.72 & 9.28 & 10.24 & 2.70 \\
& L/g intake of digestible & 0.27 & 0.22 & 0.16 & 0.05 \\
& neutral detergent fibre & & & & \\
\hline
\end{tabular}

Calculated as $\mathrm{CO}_{2} / \mathrm{O}_{2}$. 
1 Table 5 Metabolic rate Linné's two-toed sloths (Choloepus didactylus) in the present study (mean $\pm \mathrm{SD}$ ) and in other sloth species from the literature

\begin{tabular}{|c|c|c|c|c|c|c|c|}
\hline Source & Species & $\begin{array}{c}\mathrm{BM} \\
\mathrm{kg}\end{array}$ & MR & $\begin{array}{l}\mathrm{BMR} \\
\mathrm{kJ} /(\mathrm{kg}\end{array}$ & $\begin{array}{l}\text { RMR } \\
75 \cdot \text { day) }\end{array}$ & FMR & Method \\
\hline Present study & C. didactylus & 10.02 & $\begin{array}{c}186.3 \pm 31.8 \\
(173.2 \pm 22.1)^{*}\end{array}$ & & $\begin{array}{c}134.5 \pm 27.3 \\
(126.5 \pm 27.0)^{*}\end{array}$ & & Chamber respirometry \\
\hline Irving et al. (1942) & C. hoffmanni & 4.53 & 149.1 & & & & Mask respirometry \\
\hline Lemaire et al. (1969) & C. hofmanni & 4.60 & & & 148.6 & & Chamber respirometry. \\
\hline McNab (1978) & C. hoffmanni & 4.25 & & 121.95 & & & Chamber respirometry. \\
\hline $\begin{array}{l}\text { Ozorio de Almeida and } \\
\text { Branco de Fialho (1924) }\end{array}$ & B. tridactylus & 3.74 & 103.9 & & & & Chamber respirometry. \\
\hline Irving et al. (1942) & B. variegatus & 3.16 & 130.4 & & & & Mask respirometry \\
\hline Irving et al. (1942) & B. variegatus & 3.32 & & & 102.1 & & Mask respirometry \\
\hline McNab (1978) & B. variegatus & 3.79 & & 121.8 & & & Chamber respirometry. \\
\hline Nagy and Montgomery (1980) & B. variegatus & 4.08 & & & & 208.9 & Doubly-labelled water \\
\hline
\end{tabular}

2 C., Choloepus; B., Bradypus; BM, body mass; BMR, basal metabolic rate; FMR, field metabolic rate; MR, metabolic rate; RMR, resting metabolic rate.

"Excluding animal 4 with an excessively high food intake 


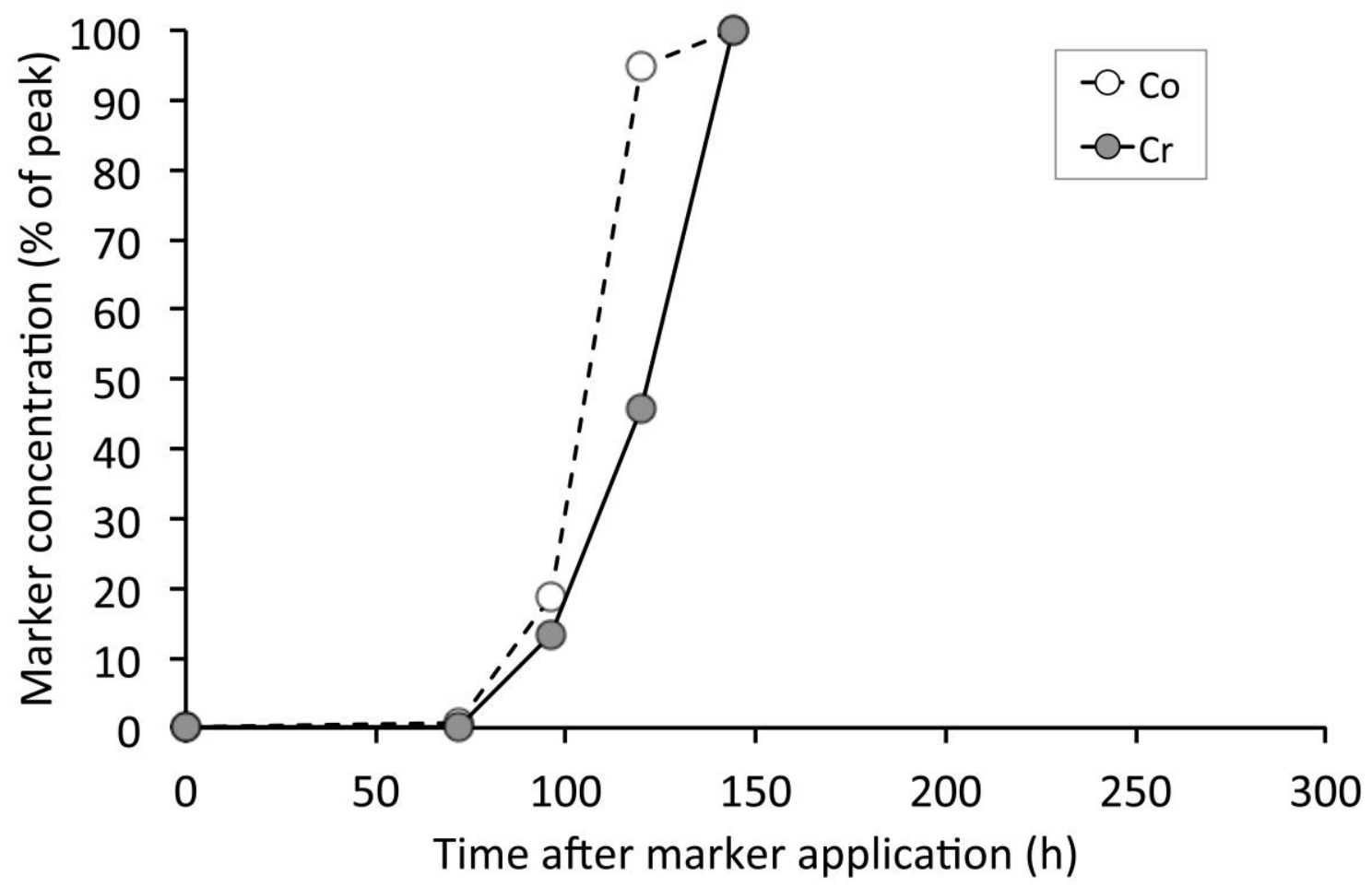




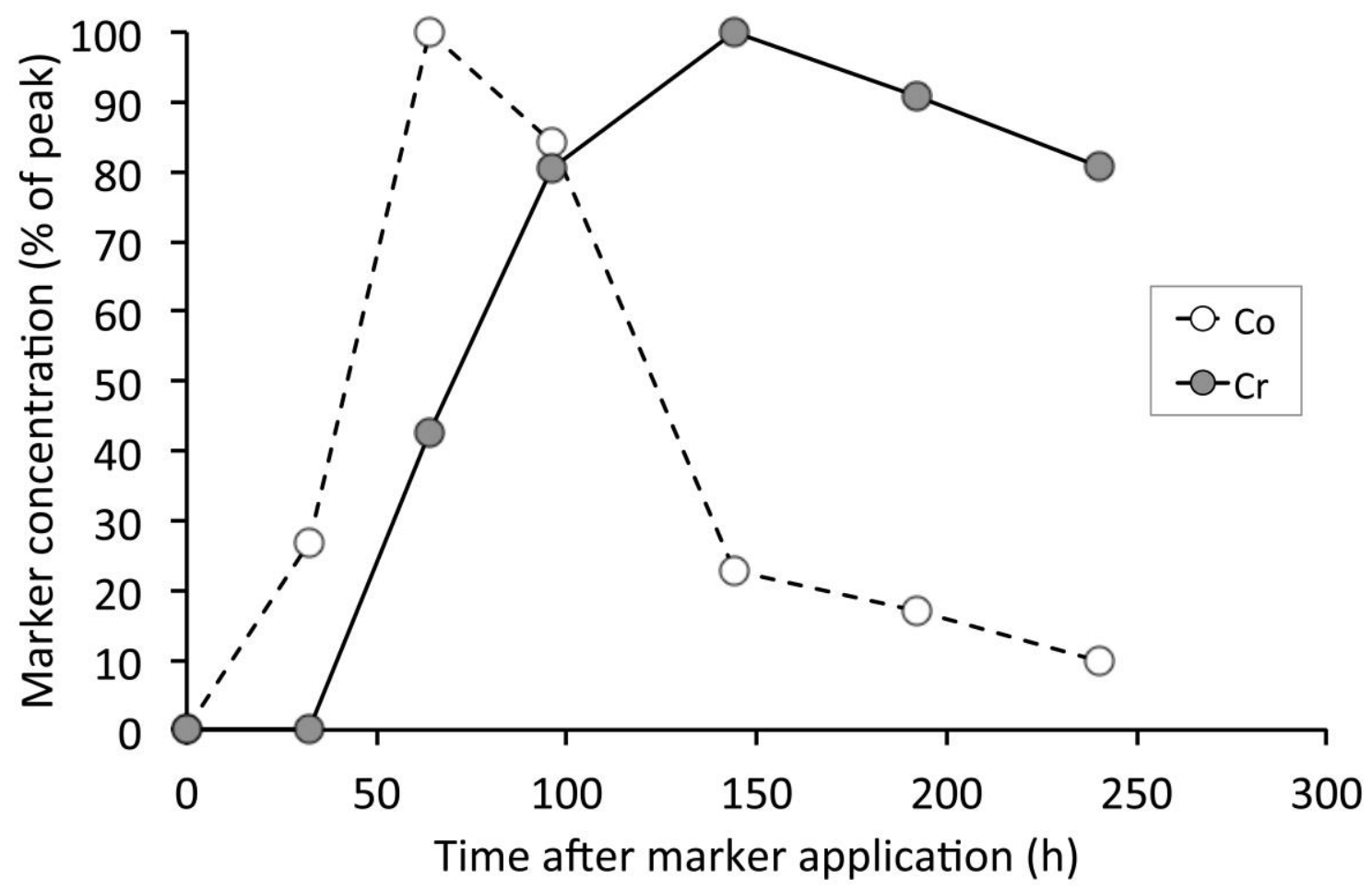




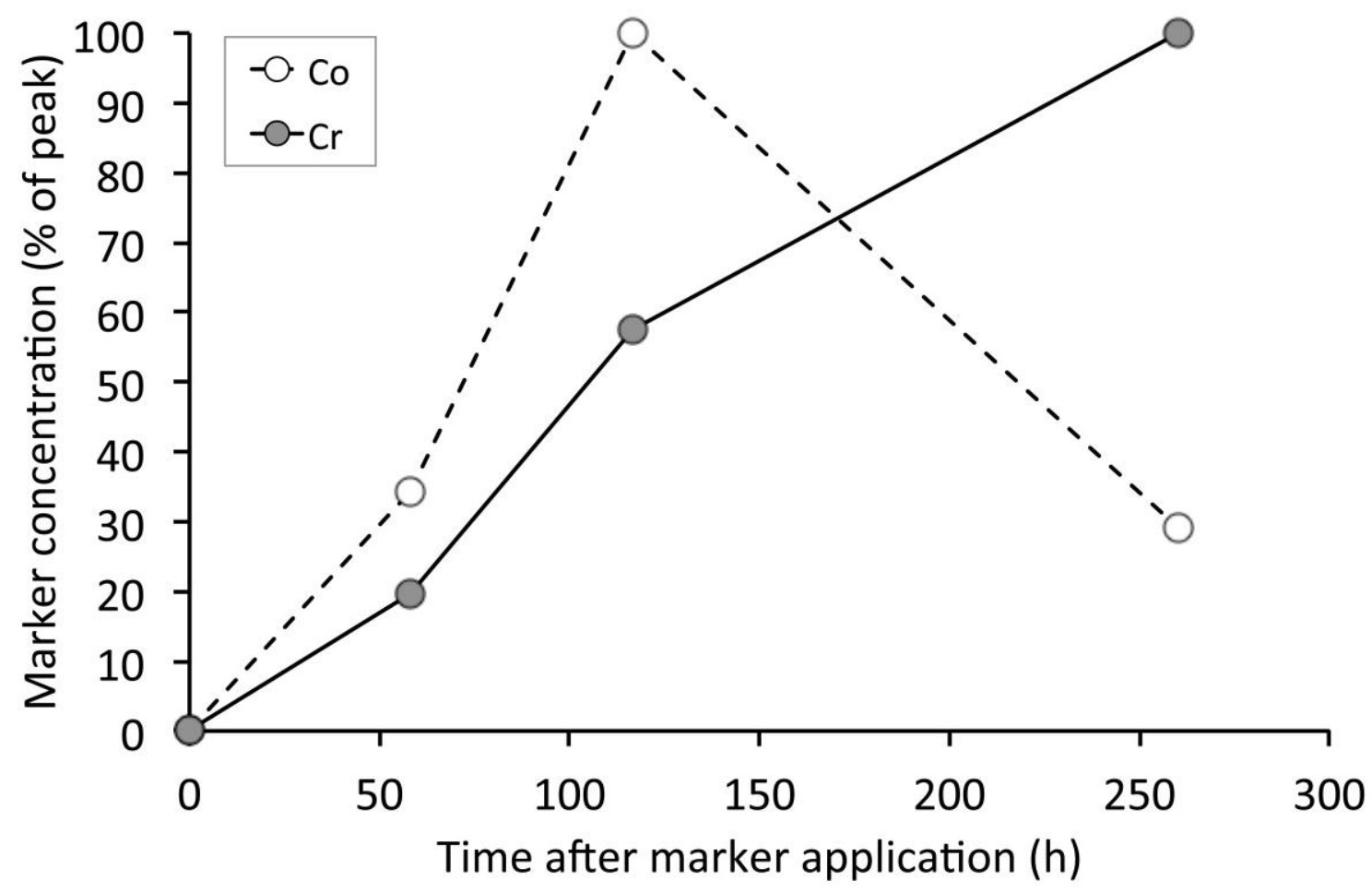




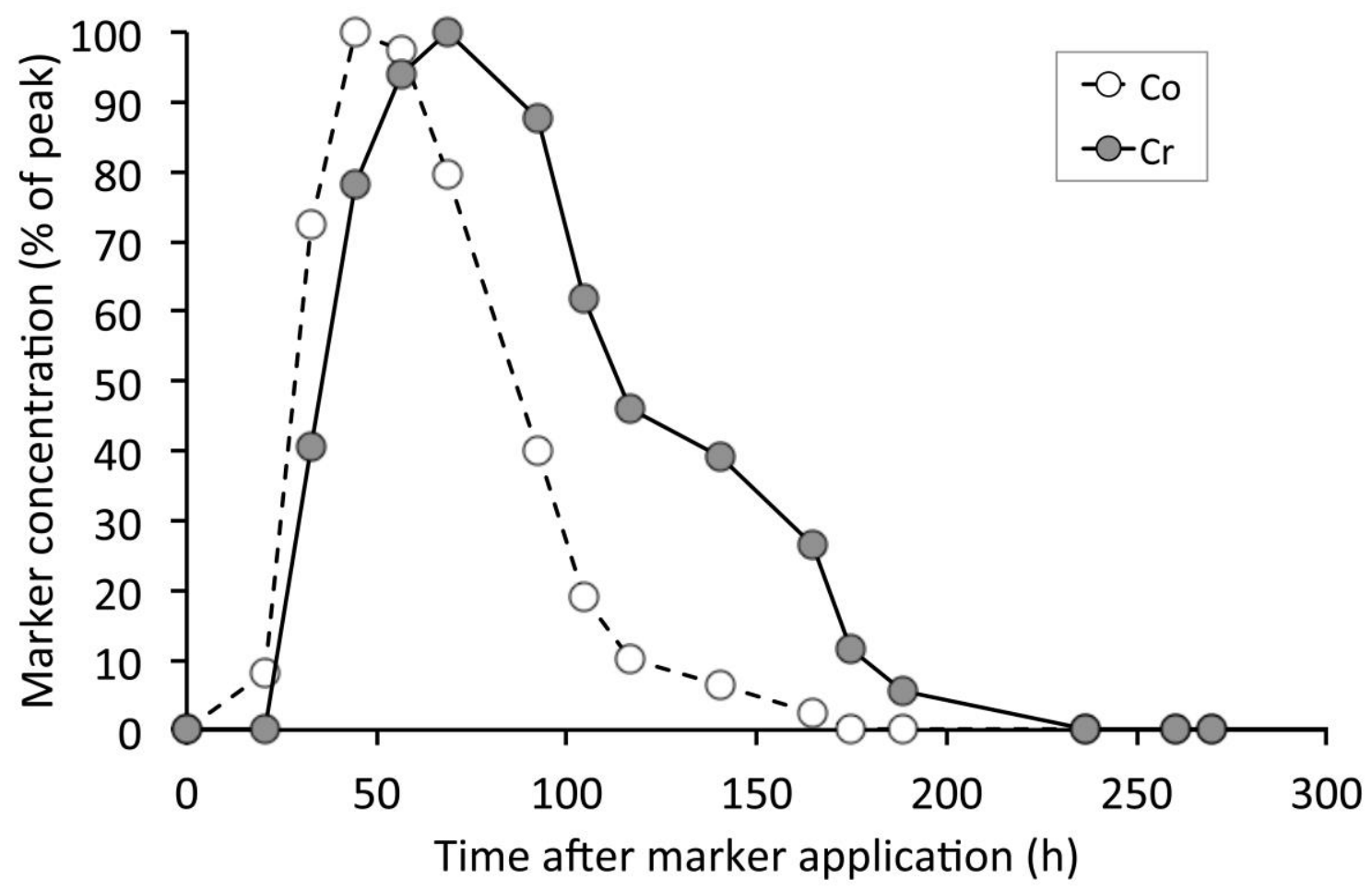




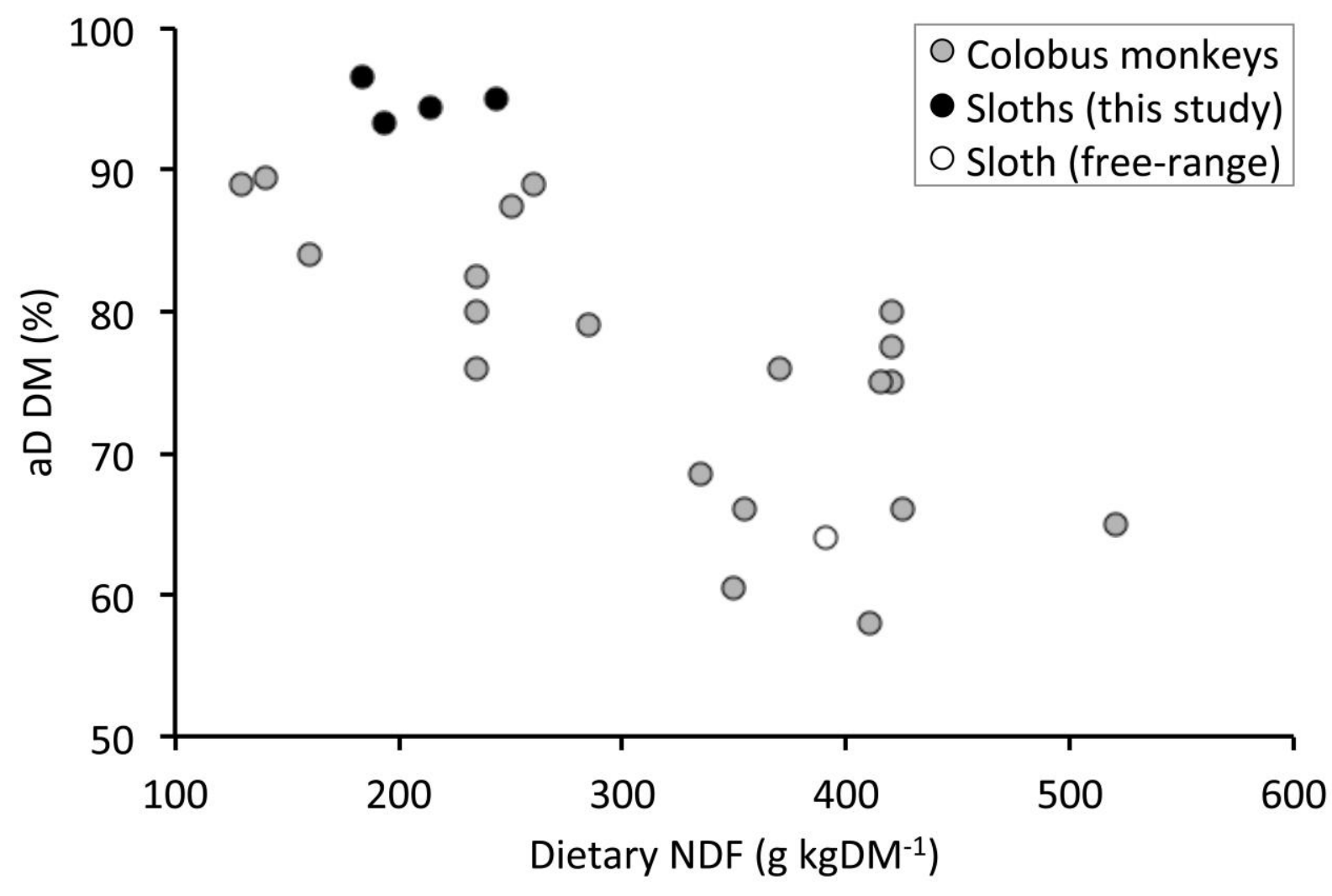




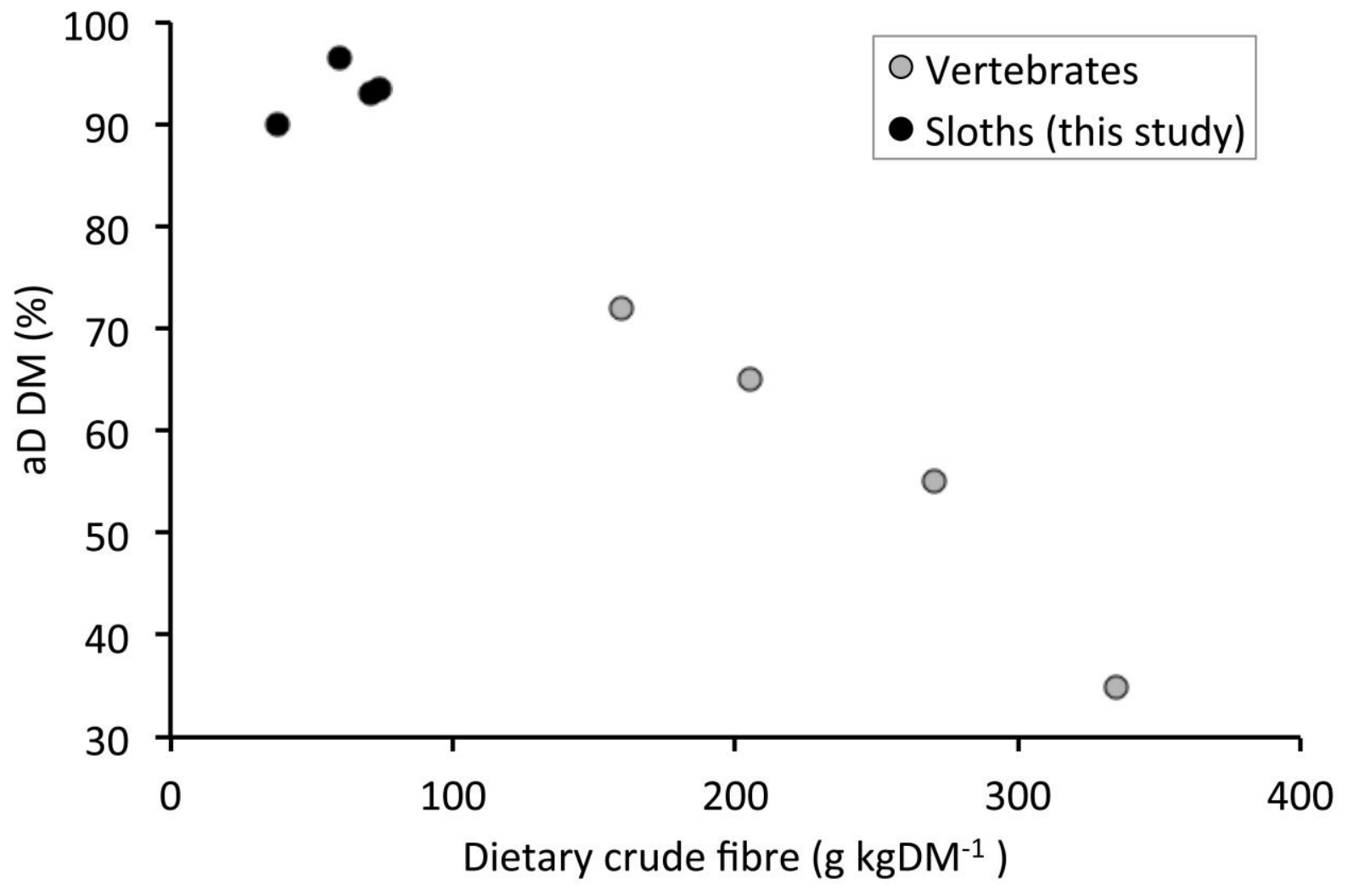




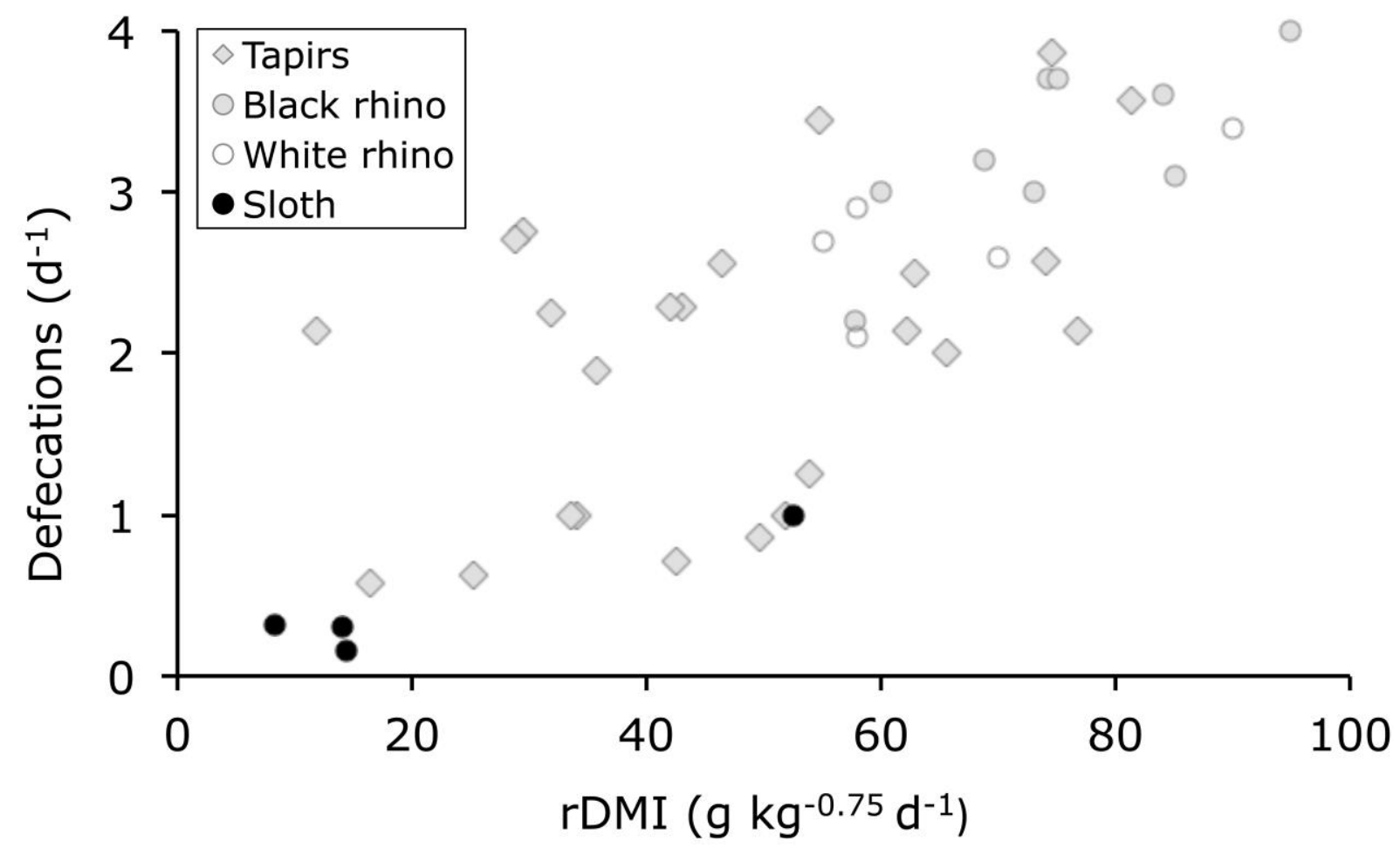




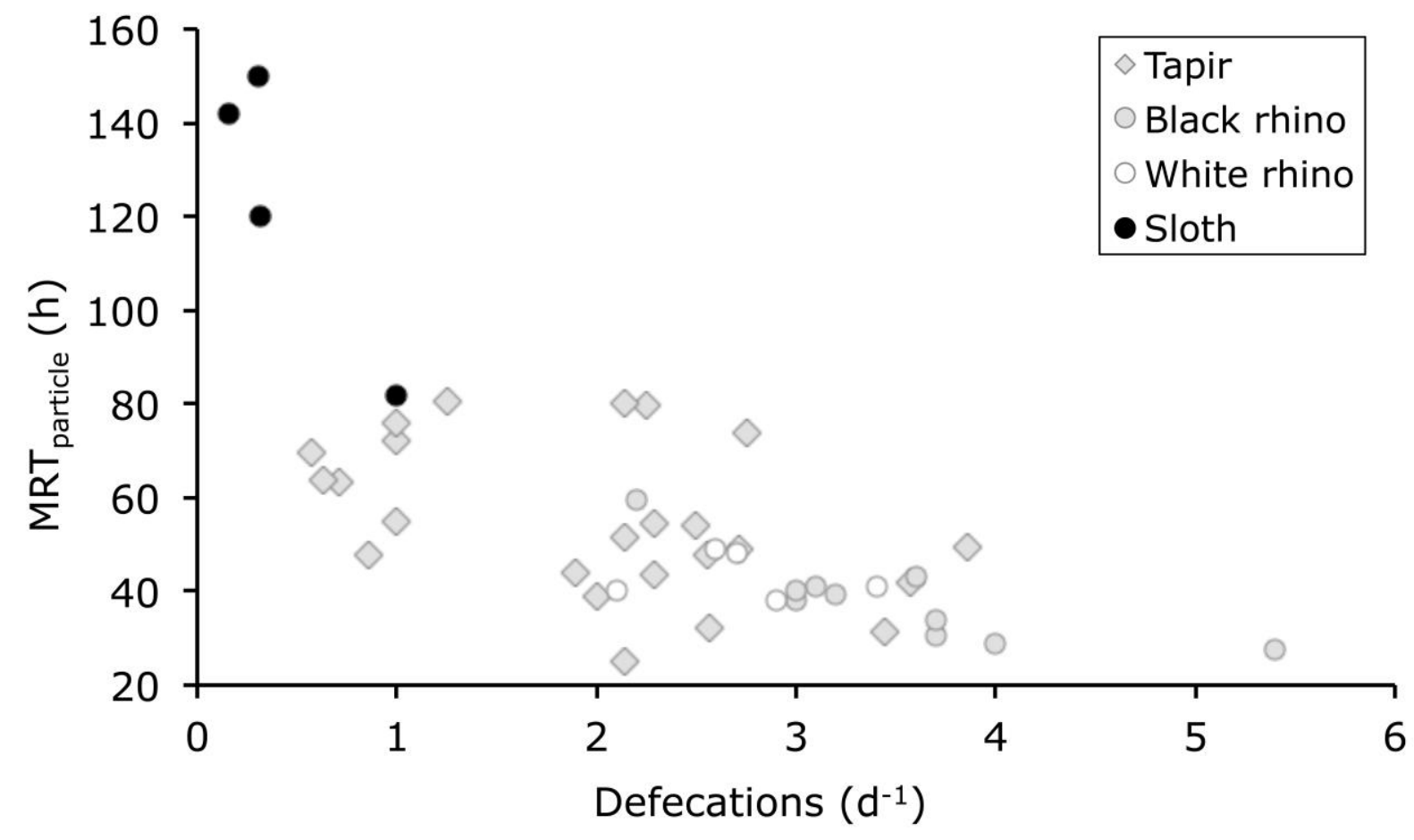




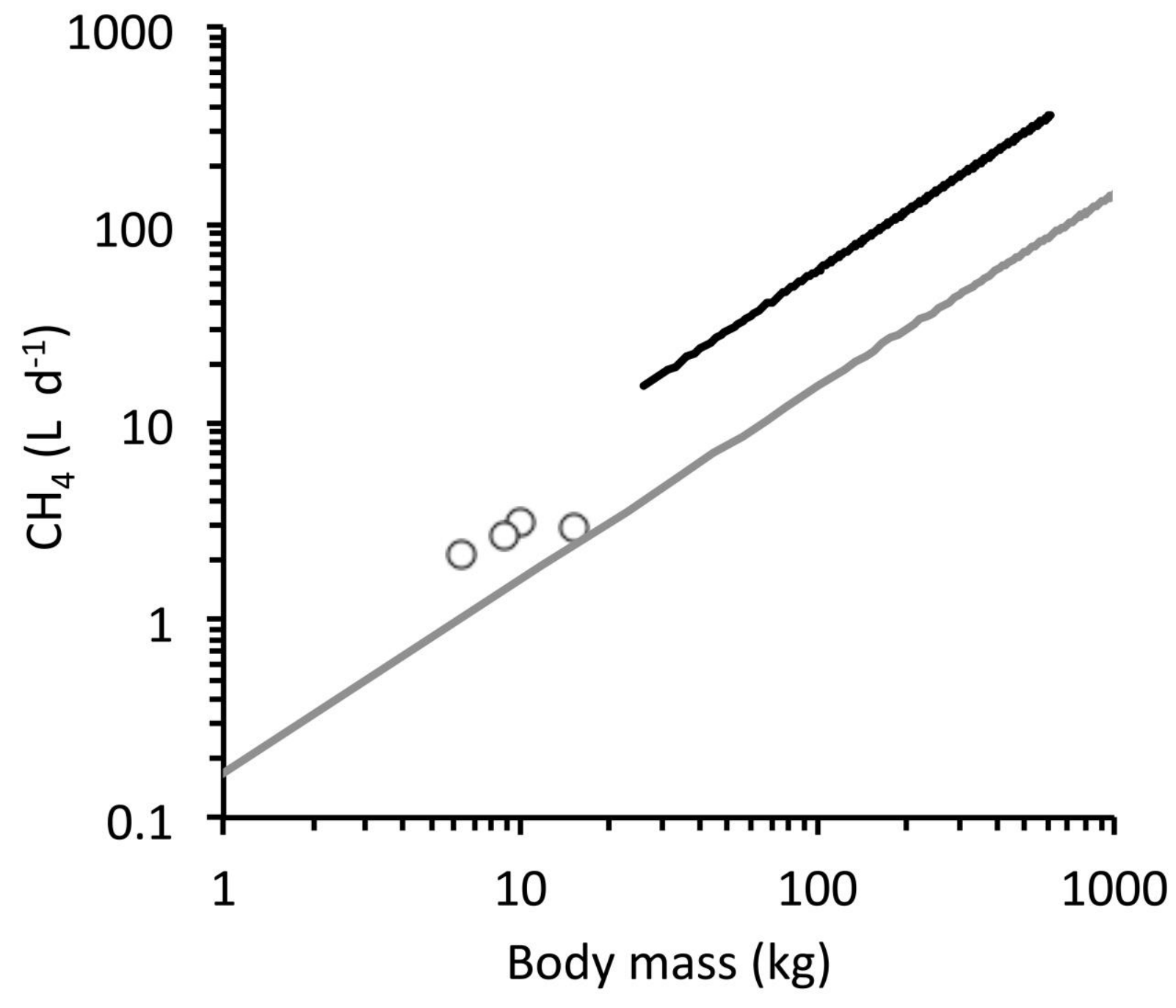




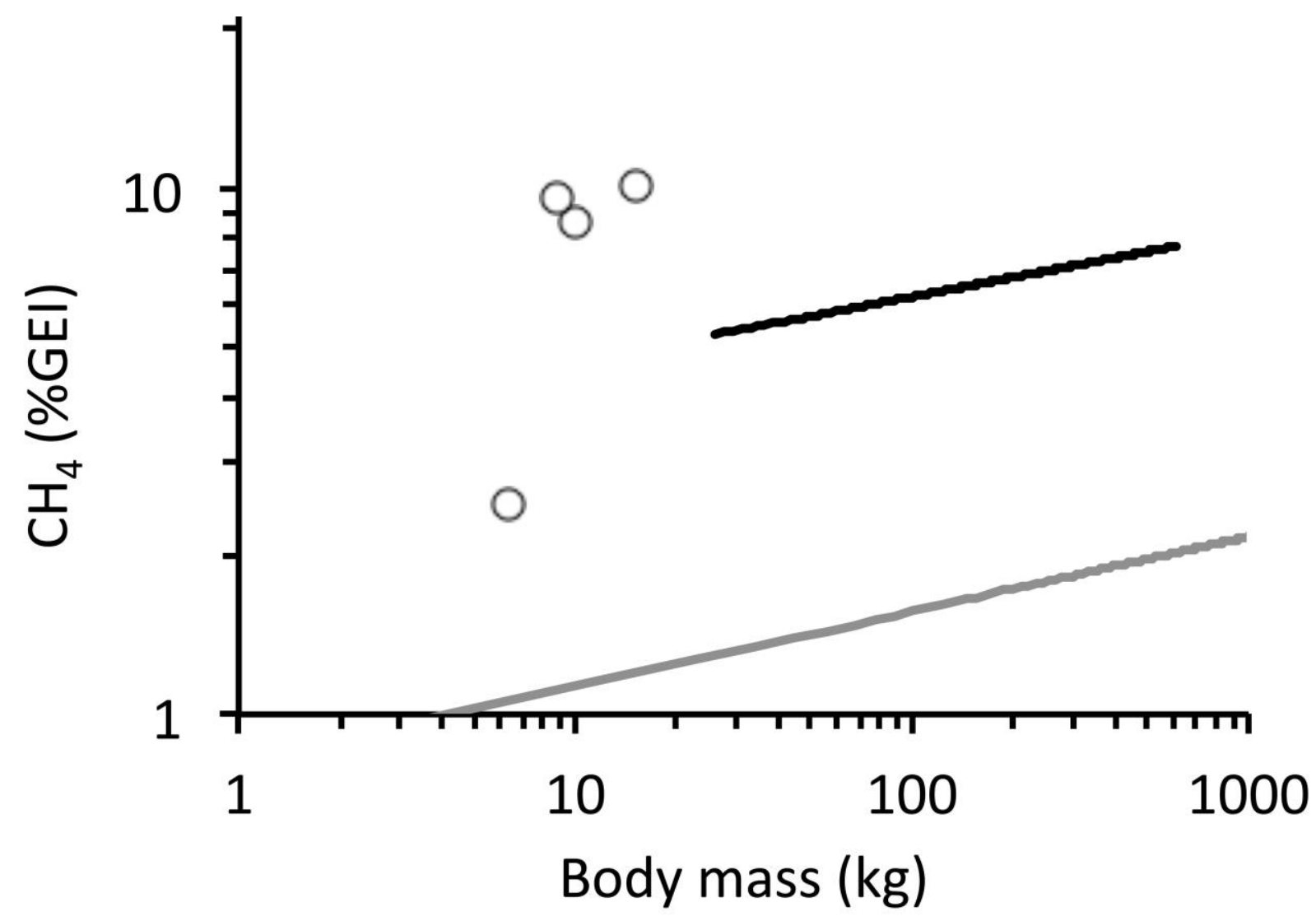




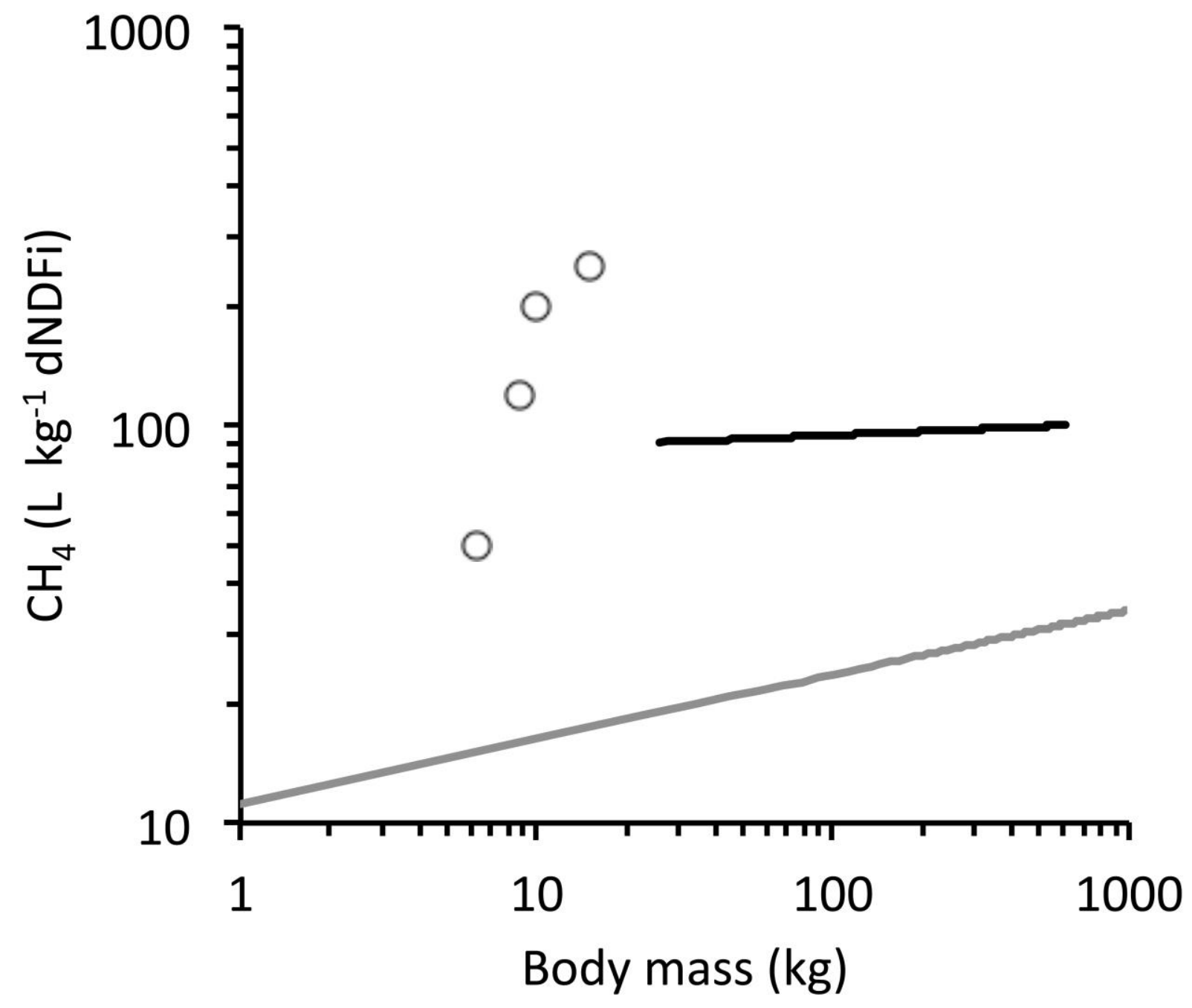




\section{Curriculum Vitae tabellarisch}

Vorname Name

Geburtsdatum

Geburtsort

Nationalität

$08 / 1995-06 / 2004$

$08 / 06 / 2004$

09/2005 - 03/2011

$30 / 03 / 2011$

$04 / 2013-05 / 2015$

$08 / 2012-03 / 2013$

$04 / 2013-01 / 2014$

$04-05 / 2015$
Catharina Vendl

21.01.1985

Berlin

Deutsch

Evangelisches Gymnasium zum Grauen Kloster

Abitur, Evangelisches Gymnasium zum Grauen Kloster

Studium der Veterinärmedizin, Freie Universität Berlin, Deutschland

Freie Universität Berlin, Deutschland

unter der Leitung von Prof. Dr. Marcus Clauss

am Departement für Kleintiere, Klinik für Zoo-, Heim- und Wildtiere

der Vetsuisse-Fakultät Universität Zürich

Direktor Prof. Dr. Jean-Michel Hatt

Nachrichtenredaktion und E-Learning-Services, Vetion.de $\mathrm{GmbH}$, Berlin, Deutschland

Doktorandin, Departement für Kleintiere, Klinik für Zoo-, Heim- und Wildtiere der Vetsuisse-Fakultät Universität Zürich 